\title{
THE CRETACEOUS-EOCENE CONTACT IN THE ATLANTIC AND GULF COASTAL PLAIN.
}

\author{
By Lloyd William Stephenson.
}

\section{INTRODUCTION.}

The Cretaceous deposits of the Atlantic and Gulf Coastal Plain are separated from the overlying Eocene and younger formations by an unconformity of regional extent. Several authors, including Harris, ${ }^{1}$ Dall, ${ }^{2}$ Vaughan, ${ }^{3}$ and Hill and Vaughan, ${ }^{4}$ have briefly described this unconformity and have stated some of the important facts in regard to the differences exhibited by the faunas on the two sides of the contact. The magnitude of these differences, however, has not been sufficiently appreciated by geologists, notwithstanding the published statements of the authors cited. Eighteen years ago Harris wrote with reference to the Gulf region:

Between the basal Eocene deposits and the uppermost Cretaceous there is in this section of the country a decided break both stratigraphic and faunal, so that not one species is known certainly to have crossed from one formation to the other. At or immediately above this line an entirely new fauna makes its appearance upon the scene.

Fourteen years ago (1900) Vaughan stated in regard to the unconformity along Frio River, Tex., that-

These data prove absolutely that there must have been a break in the sequence of sedimentation long enough to permit a complete faunal revolution.

In 1909 Stanton ${ }^{5}$ said:

The succeeding Tertiary faunas, whether on the Pacific coast, the Gulf border, or the Atlantic Coastal Plain, show a very striking change from the Cretaceous faunas that immediately precede them. The specific types are practically all different.

The object of this paper is to present additional data bearing on the contact and especially to emphasize its importance in the geologic history of the Atlantic and Gulf Coastal Plain.

\section{TREND OF THE OUTCROP AND NATURE OF THE CONTACT.}

With certain interruptions the unconformity is traceable from New Jersey to the Rio Grande and, according to Dumble, ${ }^{6}$ thence far southward into Mexico. In some places the contact is overlapped and concealed by Miocene or younger formations, and in others it is obscured by weathering and the similarity of the materials immediately below and above the unconformity. But for the greater part of the distance, where the contact is not concealed by transgressing formations, it is sharp and easily recognizable. The sea in which the basal Eocene strata were formed advanced across a land surface which had reached an old or nearly base-leveled stage of erosion, as is shown by the almost horizontal or broadly uneven attitude of the contact, which, however, presents numerous minor irregularities. Throughout much

1 Harris, G. D., The Midway stage: Bull. Am. Paleontology, vol. 1, p. 119, 1896.

2 Dall, W. H., A table of North American Tertiary horizons: U. S. Geol. Survey Eighteenth Ann. Rept., pt. 2, pp. 332-335, 1898.

3 Vaughan, T. W., Reconnaissance in the Rio Grande coal fields of Texas: U. S. Geol. Survey Bull. 164, pp. 35, 36, 1900; U. S. Genl. Survey Geol. Atlas, Uvalde folio (No. 64), pp. 2, 3, 1900.

${ }^{4}$ Hill, R. T., and Vaughan, T. W., U. S. Geol. Survey Geol. Atlas, Austin folio (No. 76), p. 6, 1902.

5 Stanton, T. W., Succession and distribution of later Mesozoic invertebrate faunas in North America: Jour. Geology, vol. 17, p. $422,1909$.

${ }^{6}$ Dumble, E. T., Tertiary deposits of northeastern Mexico: Science, new ser., vol. 33, pp. 232-234, 1911. 
of the linear extent of the Coastal Plain clays, sands; or limestones carrying marine invertebrates of Eocene age rest upon sands, clays, or marls carrying Upper Cretaceous invertebrates. The conglomeratic material at the base of the Eocene is everywhere relatively thin and usually consists of a few inches to a few feet of coarse sand or small pebbles with an intermixture of rolled chunks from the underlying formation, phosphatic nodules, casts of shells, shark teeth, and other fossil remains. Because of the marine origin of the beds below and above the contact the conditions are favorable for determining the faunal relationships of the formations. In east-central Georgia, northern Virginia, and the Potomac River region in Maryland the Eocene rests upon Lower Cretaceous deposits.

The approximate trend of the outcrop of the Cretaceous-Eocene contact and its geographic

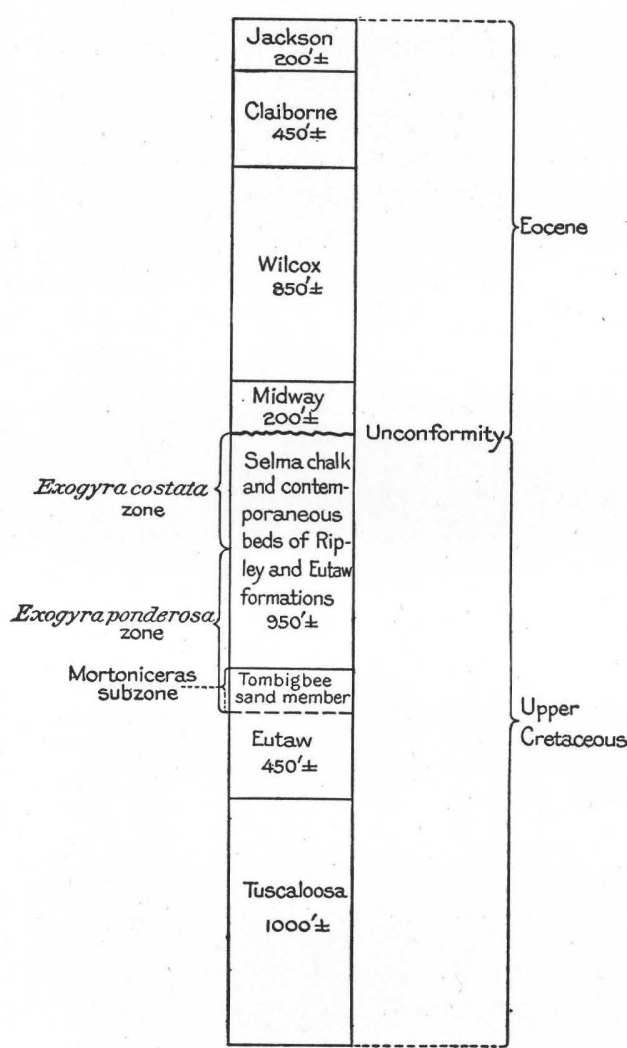

FIGURE 13.-Generalized section of the Upper Cretaceous and Eocene series and their major subdivisions in west-central Alabama and east-central Mississippi. position with reference to the fall line and to transgressing formations younger than Eocene are indicated on the map forming Plate XI.

GENERALIZED \$ECTION IN THE CENTRAL PART OF THE EASTERN GULF REGION.

A generalized section of the Upper Cretaceous and Eocene strata in the central portion of the eastern Gulf region is given in figure 13. In the Cretaceous section are the Tuscaloosa, Eutaw, and Selma formations, named in ascending order.

The Tuscaloosa is a plant-bearing formation composed of sands and clays of shallow-water origin. The lower part of the formation is correlated by E. W. Berry with the Dakota sandstone of the western interior region.

The Eutaw formation is composed of sands, in part calcareous and glauconitic, and clays, all of marine origin. The upper or Tombigbee sand member of the formation (also known as the Mortoniceras subzone) carries a purely marine fauna which includes 70 or more species. Several lines of evidence seem to show with a fair degree of certainty that the Mortoniceras subzone is approximately synchronous with the Niobrara formation of the western interior region.

The Selma chalk has its fullest development in west-central Alabama and east-central Mississippi, and here the formation as a whole may be roughly correlated with the Montana group of the western interior region. This chalk formation merges to the east in Alabama and Georgia into nonchalky marine sands and clays referred to the Ripley formation, which carries an abundant marine invertebrate fauna, and to the northwest and north in Mississippi and Tennessee into similar sands and clays referred in part to the Ripley formation and in part to the Eutaw formation.

Two major faunal zones have been distinguished in the Upper Cretaceous deposits. The Exogyra ponderosa zone includes the Tombigbee sand and approximately the lower half of the Selma chalk; the Exogyra costata zone includes the upper part of the Selma chalk. These two zones are traceable through practically the entire linear extent of the Atlantic and Gulf Coastal Plain. In west-central Alabama and east-central Mississippi the Selma is unconformably overlain by the Midway, an invertebrate-bearing group of marine origin, and in ascending order the Midway is succeeded by the Wilcox, Claiborne, and Jackson groups. 


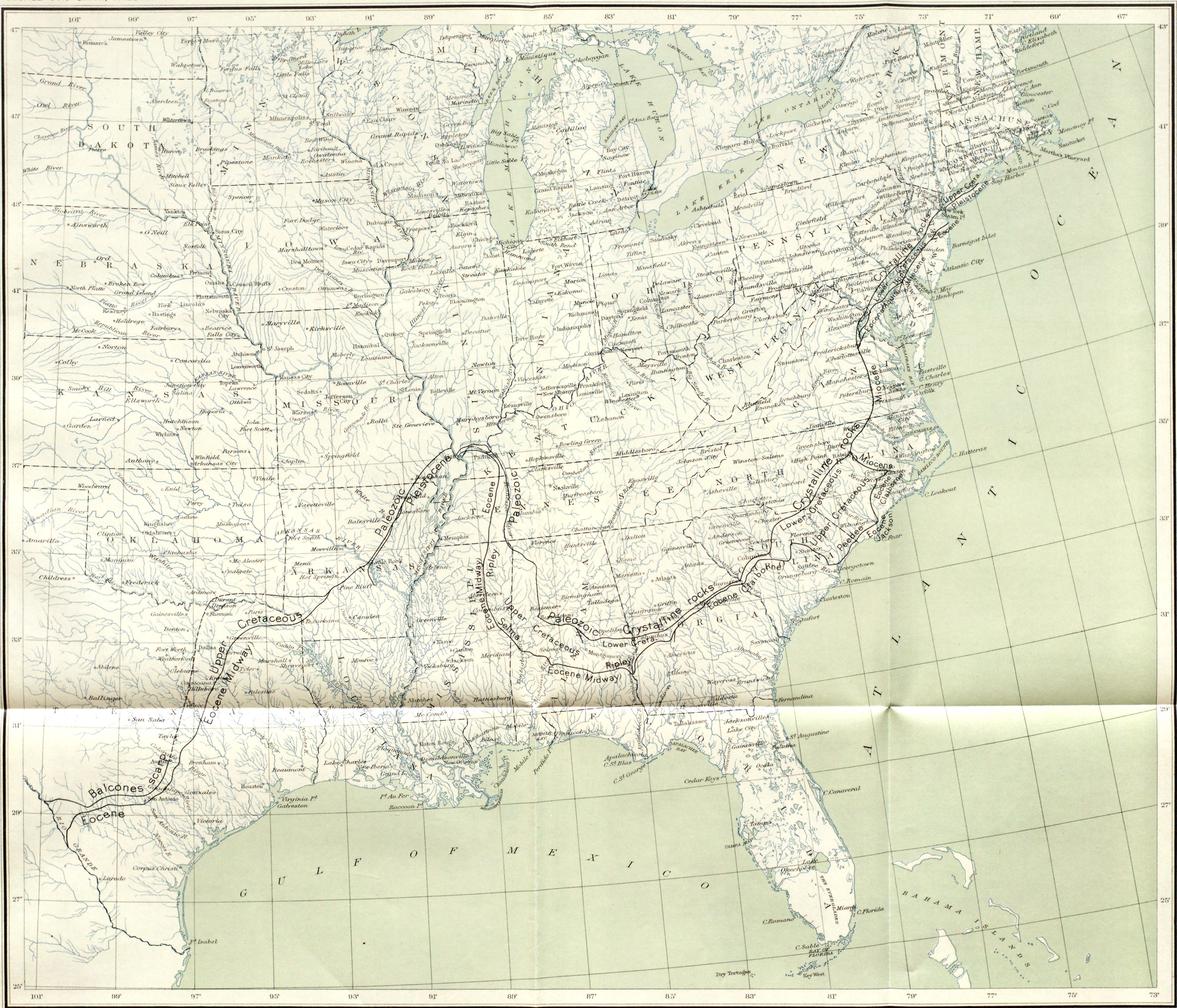

MAP SHOWING APPROXIMATE TREND OF THE CRETACEOUS-EOCENE CONTACT IN THE ATLANTIC AND GULF COASTAL PLAIN AND ITS GEOGRAPHIC RELATION TO THE PALEOZOIC AND CRYSTALLINE ROCK BOUNDARY, AND TO TRANSGRESSING FORMATIONS YOUNGER THAN EOCENE 


\section{FORMATIONS IN CONTACT ELSEWHERE IN THE ATLANTIC AND GULF COASTAL PLAIN.}

From a point near Houston, Chickasaw County, Miss., to Tennessee the Midway rests upon the Ripley formation; farther north, in Tennessee, Kentucky, and southern Illinois, the deposits immediately below and immediately above the Cretaceous-Eocene contact are of shallow-water origin and so far as known are barren of invertebrates. From central Alabama eastward to central Georgia the Midway rests upon the Ripley formation, in part upon typical marine beds and in part upon shallow-water deposits which have been designated the Providence sand member of the Ripley formation.

In east-central Georgia and southwest-central South Carolina the Claiborne group of the Eocene transgresses northwestward across both the older Eocene and the Upper Cretaceous and rests upon the Lower Cretaceous. The Upper Cretaceous reappears in eastern South Carolina, and at Wilmington, N. C., the Peedee sand, of the Upper Cretaceous series, is overlain by the stratigraphic equivalent of the Jackson, the youngest Eocene division. A little farther north deposits correlated with the Claiborne overlie the Peedee sand. In northeastern North Carolina and southeastern Virginia the Eocene and Cretaceous are entirely transgressed by the Miocene, which extends westward to the fall line. Farther north in Virginia the Lower Cretaceous and Eocene reappear from beneath the Miocene, and in Maryland the Upper Cretaceous reappears from beneath the Eocene. In Maryland the Aquia formation, of the Eocene, which is correlated with the lower part of the Wilcox of the Gulf region, rests unconformably in part upon the Matawan formation and in part upon the Monmouth formation, of the Upper Cretaceous. The Monmouth, the younger of the two formations last named, corresponds approximately to the Exogyra costata zone of the Gulf region. In New Jersey the Miocene again transgresses upon the Upper Cretaceous, although the Shark River marl, of the Eocene, which is probably about contemporaneous with the Claiborne, appears in Monmouth County, where it rests upon the Manasquan formation, of the Upper Cretaceous.

From the vicinity of Arkadelphia, Ark., southwestward to the Rio Grande, Upper Cretaceous deposits bearing marine invertebrates and roughly corresponding in age to the Exogyra costata zone of the eastern Gulf region are overlain almost continuously by marine Eocene strata which Harris has correlated with the Midway. The writer's work in southwestern Texas has resulted in the discovery of the contact at two localities and its approximate determination at several other localities along the Rio Grande and in its approximate determination at several places in Uvalde and Medina counties. In at least one area in southwestern Texas the Midway is transgressed by younger Eocene strata.

\section{CRETACEOUS AND EOCENE FAUNAS COMPARED.}

At no known place between Maryland and the Rio Grande are the Upper Cretaceous deposits immediately below the Eocene contact markedly younger than the upper part of the Exogyra costata zone of the eastern Gulf region, nor are the Eocene deposits immediately above the contact older than the Midway. In this connection it should be stated that the Rancocas and Manasquan formations of New Jersey, which carry only a meager fauna, are thought to be somewhat younger than the Exogyra costata zone, and the upper part of the Escondido formation of southwestern Texas may be a little younger than that zone, although its fauna is composed of strictly Mesozoic types, of which the genus Sphenodiscus is the most striking example. The time represented by the unconformity at other places throughout the Coastal Plain is therefore approximately equal to or greater than the time represented by the unconformity in the eastern Gulf region. As the faunas above and below the contact are best known in the Gulf region the available data relating to that region form the chief basis for the statements which follow.

During the time represented by the unconformity separating the Cretaceous and Eocene strata of the eastern Gulf region some very important changes took place in the molluscan life of the region. A preliminary study of the faunas has shown that 168 or more species belonging to the subkingdom Mollusca existed in the zone of Exogyra costata of the Upper 
Cretaceous. Of these not a single species is known with certainty to have been found in the basal Eocene or Midway formation. Several species of Cretaceous mollusks have been reported from basal Eocene beds at different places in the Atlantic and Gulf Coastal Plain, but when the records are critically examined more or less uncertainty is found in each record, either as to the correctness of the identifications or as to the authenticity of the localities at which they were reported to have been found.

The 168 species of mollusks in the zone of Exogyra costata represent 89 genera. At least 20 of the more common of these genera became extinct before the Midway formation began to be deposited, and these are enumerated in the list which follows. One whole order, the Ammonoidea, which included five or more genera, entirely disappeared.

Genera common in the zone of Exogyra costata (Upper Cretaceous), which became extinct before the deposition of the Midway formation (Eocene).

Breviarca.

Nemodon.

Gervilliopsis.

Inoceramus.

Exogyra.

Paranomia.

Liopistha.
Cyprimeria.

Legumen.

Enona.

Linearia.

Leptosolen.

Perissolax.

Pugnellus.

\author{
Belemnitella. \\ Order Ammonoidea: \\ Baculites. \\ Scaphites. \\ Sphenodiscus. \\ Hamites. \\ Turrilites.
}

The genus Trigonia, which is common in the zone of Exogyra costata, does not appear in the Eocene of the Atlantic and Gulf Coastal Plain but occurs rarely in the post-Cretaceous in other parts of the world. One genus, Hamulus, belonging to the subkingdom Vermes, or worms, became extinct. Some of the smaller forms of life, such as Foraminifera, Bryozoa, and Ostracoda, have not been studied critically, and it is not known what changes may have taken place among them. However, R. S. Bassler has found that a bryozoan fauna which occurs in the Rancocas, the youngest.but one of the Upper Cretaceous formations of New Jersey, reappears in part with certain varietal changes in the Aquia formation (Eocene) in Maryland.

Although practically all the species of mollusks in the Midway formation are different from those found in the underlying Cretaceous, the number of genera that make their first appearance in the Midway is probably less than the number of Upper Cretaceous genera that became extinct in the interval represented by the unconformity. However, using Harris's paper, already cited, ${ }^{1}$ as principal authority, the writer has been able to note at least seven common genera in the Midway that are not found stratigraphically below that level in the eastern Gulf region; these are Chama, Venericardia, Meretrix, Mazzalina, Calyptraphorus, Mesalia, and Enclimatoceras. Some of these genera are known in the Upper Cretaceous in other parts of the world.

\section{MAGNITUDE OF THE FAUNAL CHANGES.}

The following comparisons will give some idea of the magnitude of the faunal changes that took place during the time represented by the unconformity. The Mortoniceras subzone of the Eutaw formation, which is thought to correspond approximately in age to the Niobrara of the western interior region, has yielded about 70 species of mollusks representing about 43 genera. Of these, 40 species and all but two or three of the genera range upward to the top of the Cretaceous. During the time required for the deposition of the beds carrying the Mortoniceras fauna and the overlying strata composing the Selma chalk and its nonchalky representatives, and probably during the time represented by the entire Upper Cretaceous section of the Chattahoochee region, the faunal changes were not nearly so great as those which occurred during the time that elapsed between the deposition of the uppermost Cretaceous strata and that of the lowermost Eocene strata of the area-that is, during the time represented by the hiatus-for at the close of the period of deposition 40 out of 70 species and all but two or three of the 43 genera survived, while at the close of the 
period of erosion, out of 168 species representing 89 genera, few if any species survived, and 20 or more common genera, including one whole order, became extinct.

T. W. Vaughan, who has a wide acquaintance with the Tertiary and Quaternary faunas: of the eastern United States, is authority for the almost startling statement that "the changes: that took place in the marine animal life of the Atlantic and Gulf Coastal Plain during the time represented by the unconformity separating the Cretaceous and Eocene of this area are more striking than the changes that have taken place between earliest Midway time and the present day, for no great orders comparable to the Ammonoidea that lived during Midway time have become extinct."

\section{CRETACEOUS AND EOCENE FLORAS COMPARED.}

The evidence afforded by the Cretaceous and Eocene floras is in substantial agreement with that supplied by the invertebrates. The following is quoted from a letter received from Mr. E. W. Berry, of Johns Hopkins University:

With regard to the Upper Cretaceous and Eocene floras of the eastern Gulf region, their differences are profound, and I believe the unconformity at the base of the Midway represents a very long interval. The last extensive Cretaceous floras in the Gulf region are, of course, a good way from the end of the Cretaceous, but they are totally different from the plants collected near Earle, Tex., in beds believed to belong to, the Midway formation. Even when comparisons are made between these Midway (?) plants and the Wilcox flora of the Gulf and the late Cretaceous of the Rocky Mountain province, the contrast is just as marked, unless you are prepared to call the Denver formation Cretaceous. There are a number of Denver plants in the Gulf Eocene, but I do not recall a single Laramie plant.

\section{INTERPRETATION OF THE HIATUS.}

In an attempt to explain the differences exhibited by the faunas found in the beds below and above the Cretaceous-Eocene contact several factors are to be considered, including time, the physical changes that may have caused the extinction or the more rapid evolution of the forms of marine life, and the migration of new forms into the area. The unconformity that separates these deposits, extending throughout the length of the Atlantic and Gulf Coastal Plain of the United States and far into Mexico is, in itself, an evidence both of a considerable lapse of time and of great diastrophic movements. The area which was submerged during Upper Cretaceous time was elevated and the shore line retreated far to the east and south, probably a considerable distance beyond the present shore line and perhaps nearly to the edge of the continental shelf. The faunas were thus forced into new environments, which doubtless contributed in part to the extinction of old genera and species and to the development of new species. There is, however, little, if any, evidence of marked changes in climate or in the temperature of the marine waters.

There is evidence that after the close of the Cretaceous period as recorded and before the beginning of the earliest recorded Eocene deposition some new forms came into the Atlantic and Gulf Coastal Plain province from an outside province or provinces. But the number of genera thus introduced is probably relatively small compared with the number of genera that survived from the Cretaceous of the same province, though represented by new species. The faunal changes are therefore believed to be more largely due to evolutionary development from forms that previously existed in the same province than to new elements introduced from outside provinces.

It is pretty generally conceded by paleontologists that evolutionary changes have proceeded more rapidly at certain times during the earth's history than at other times; but if this quickening of development is admitted the hiatus, in order to produce the observed changes, must have been of great duration even when measured in terms of geologic time. How much of that time should be classed with the Cretaceous and how much with the Tertiary can not be determined with the available data. It is reasonable to conclude, however, that Cretaceous time did not end with the deposition of the uppermost Cretaceous strata now preserved, nor did Tertiary time begin with the deposition of the lowermost Eocene strata. The line separating the two periods probably lies somewhere toward the middle of the hiatus. 


\section{UNPUBLISHED DETAILS RELATING TO THE CONTACT.}

During the last eight years the writer has had occasion to examine the CretaceousEocene contact at many places between Virginia and the Rio Grande in Texas, and some of his observations have already been published. Many of the localities had been previously visited by geologists and the results of their studies put on record. Perhaps the majority of the published sections are essentially correct, so that for the present purpose their description would be an unnecessary duplication. Several sections in Alabama and Mississippi in which the contact is exposed have been incorrectly interpreted, and a restatement of the age and structural relations is necessary. New data in regard to the contact in Alabama, Mississippi, and Taxas are also given on succeeding pages.

\section{EASTERN GULF REGION.}

\section{VICINITY OF CLAYTON, ALA.}

Langdon ${ }^{1}$ mentioned an outcrop of Midway limestone in a cut on the Central of Georgia Railway east of Clayton, Barbour County, Ala., as follows: "Two miles east of Clayton this rock may be seen cropping out in a cut on the Clayton \& Eufaula Railroad [now Central of Georgia Railway]."

Harris studied this section and in 1896 published a description of it, ${ }^{2}$ which is in essential agreement with the one here given. Although he recognized the unconformity between layers 1 and 2 of the section given below, he did not interpret it to be the contact between the Cretaceous and Eocene. In 1910 the writer carefully examined this cut and other exposures along the railroad immediately to the east and found what he regarded as the CretaceousEocene contact.

Section in cut of Central of Georgia Railway $1 \frac{1}{2}$ miles east of Clayton, Ala.

lws Gwo Eocene (Midway group): $\quad$ Feet.

ald bra 6. Deep-red ferruginous sand, grading downward into light-colored, rather fine sand.... 10-12



4. Hard fossiliferous limestone (Clayton limestone) in which were recognized Ostrea crenutimarginata Gabb, Ostrea sp., Turritella mortoni Conrad, Turritella sp., and Venericardia sp.; the limestone appears to pass into sand toward the east.............. 5

3. Fine yellow, slightly micaceous massive sand with small oysters in the upper part. . . 5-6 (A few rods east of the end of the cut and 1 or 2 feet lower than the base of layer No. 3 the section is continued as follows:)

2. Strongly ferruginous sand and sandy clay, partly indurated, with small particles of

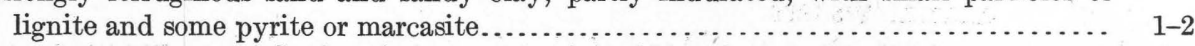

Sharp, unconformable contact presenting minor irregularities.

Upper Cretaceous (Providence sand member of Ripley formation):

1. Greenish-gray compact coarse sand. 5
-6 
TROY, ALA.

The contact between the Cretaceous and Eocene outcrops north of Troy in the northwardfacing slope of the Conecuh River valley. Figure 14 is a generalized section from the town northward to the river, a distance of about 3 miles, showing the relation between the Cretaceous and Eocene strata. The details and approximate thicknesses of the beds are as follows:

$$
\text { Section from Troy, Ala., to Conecuh River. }
$$

Eocene (Midway group):

$f$. Deep-red weathered massive sands, forming the surfacematerials at Troy, grading downward into less weathered massive sands............................... 80

e. Gray glauconitic sand............................ 20

d. Limestone in which the following Eocene mollusks were recognized: Ostrea crenulimarginata Gabb, Venericardia sp., Turritella mortoni Conrad (Clayton limestone)...... 15

c. Light-gray massive argillaceous sand .................... 30

Probable unconformity. The exact contact between the Cretaceous and Eocene was not seen clearly exposed in the vicinity of Troy, but the general relation of the deposits as observed in numerous exposures justifies the belief that the contact lies immediately above layer $b$ at the point indicated in figure 14.

Upper Cretaceous (Ripley formation):

$b$. Drab to yellowish and reddish fine to coarse sands with interbedded subordinate lenses and layers of massive clay, lenses of laminated clay, white clay films and grains, and some clay balls (Providence sand

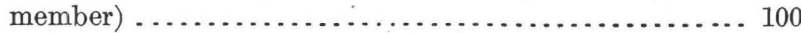

a. Dark-gray to black argillaceous, very micaceous sand or sandy clay, containing fossils in the form of soft casts; Crassatellites pteropsis Conrad and Breviarca sp. recognized.......................................

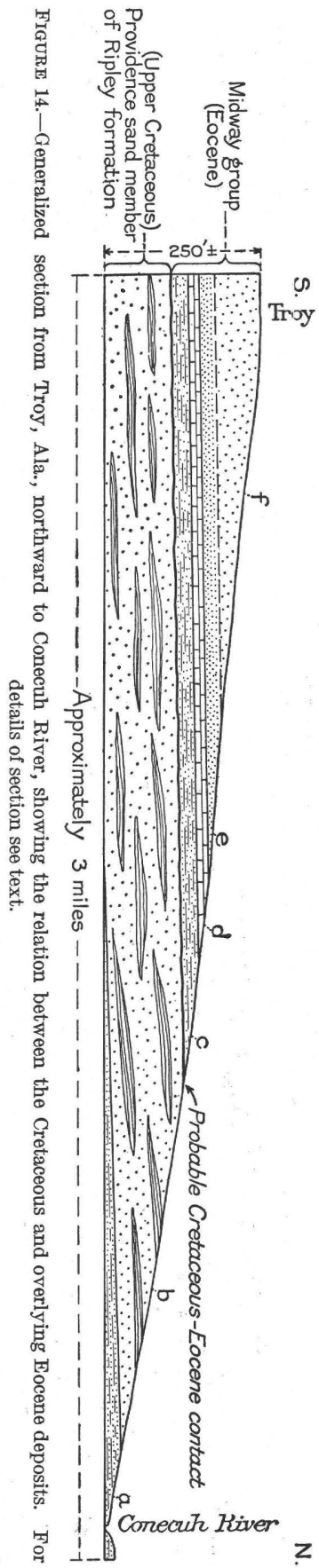

Layers $a$ and $b$ of the section are exposed along the road leading northward from Troy to Orion; layers $d$ to $f$ are exposed in deep gullies at the headwaters of a small branch just north of Troy.

BRIDGEPORT LANDING, ALABAMA RIVER, ALA.

Smith and Johnson ${ }^{1}$ in 1887 described in detail the section exposed in the bluff at Bridgeport Landing, Alabama River, Wilcox County, Ala. With the exception of 10 feet of terrace materialis at the top of the bluff, the whole section embracing a thickness of about 50 feet of strata was assigned by them to the Ripley formation (Upper Cretaceous).

In 1910 the writer, in company with Dr. Smith, visited this landing and found in an indurated layer 10 feet above water level the Eocene fossil Enctimatoceras utrichi White, and a few feet higher Venericardia sp. It was at once agreed that the strata belonged to the Midway group and that no Cretaceous beds appeared above water level.

1 Smith, E. A., and Johnson, L. C., Tertiary and Cretaceous strata of the Tuscalıosa, Tombigbee, and Alabama rivers: U. S. Geol. Strvey Bull. 43, p. 74, Pl. XIX, fig. 3, 1887. See also Smith, E. A., Johnson, L. C., and Langdon, D. W., jr., On the geology of the Coastal Plain of Alabama, Alabama Geol. Survey, p. 262, Pl. XVI, 1894 
The Cretaceous-Eocene contact is clearly exposed in a bluff on Alabama River below Old Canton Landing, Wilcox County, Ala. This section was described in 1887 by Smith and Johnson, ${ }^{1}$ but the contact was not recognized and that portion of the section which belongs to the Midway was referred to the Ripley formation of the Upper Cretaceous. The locality was visited by the writer in 1909 and the results expressed in the section given below were obtained. In 1910 he again went to the locality, in company with Dr. Smith, who concurred in this interpretation.

\section{Section at Old Canton Landing, Alabama River, Ala.}

Pleistocene (terrace deposit): Red ferruginous pebbly sand with gravel Feet. in the lower portion (poorly exposed toward base) . . . . . . . . . . . $25-30$ Unconformity.

Eocene (Midway group): The steep slope is largely covered with vegetation, but in the road leading down to the landing nodular layers of calcareous sandstone are poorly exposed, and along the bluff below the landing, immediately above the contact, is 10 to 20 feet of greenish-gray, more or less glauconitic calcareous sandstone, underlain in depressions in the Selma chalk by loose glauconitic gray sand with rows of indurated concretionary masses (see Pl. XII), and in places rolled lumps of Selma chalk and reworked Cretaceous fossils. Along the immediate base of the Midway is a gray quartzite-like rock varying in thickness from a film to 1 foot. In the calcareous sandstone the following Eocene fossils, identified by C. Wythe Cooke, were obtained: A coral, Terebratulina? sp., Cucullæa saffordi (Gabb), Ostrea pulaskensis Harris, Turritella sp., Levifusus trabeatus (Conrad) var.? (U. S. G. S. collection 5480); in addition to these the writer recognized Venericardia sp. and Enclimatoceras ulrichi White.......... 90-105 Unconformity.

Upper Cretaceous (Selma chalk): Light-gray chalky limestone, typical in upper part, somewhat sandy below; contains 30 or more characteristic species of the Exogyra costata zone of the Upper Cretaceous.....

The strata exposed in the lower 25 or 30 feet of the bluff exhibit numerous minor faults involving both the Cretaceous and Eocene. Figure 15 is a rough sketch of the structural features exhibited by the rocks exposed along the face of the bluff. (See also Pl. XIII, A.)

\section{MOSCOW LANDING, TOMBIGBEE RIVER, ALA.}

The Cretaceous-Eocene contact is well exposed at Moscow Landing, on Tombigbee River about 14 miles below Demopolis, Ala. In 1887 the beds above the contact were referred by Smith and Johnson ${ }^{2}$ to the Ripley formation (Upper Cretaceous), but in 1910 this mistaken correlation was partly corrected by Smith. ${ }^{3}$ This exposure has been examined by T. W. Vaughan, E. W. Berry, and the writer, and all agree that the sandstone and conglomeratic lenses occupying depressions in the Selma chalk and overlain by strata of undoubted Midway age are basal Eocene deposits, and not Cretaceous deposits, as interpreted by Smith.

The Eocene sea advancing across an uneven surface planed off the tops of the elevations and rapidly filled the depressions. After the hollows were completely filled, and while the sea was still shallow, the waves continued for

1 Op. cit., pp. 74-75, Pl. XIX, fig. 4. See also Smith, Johnson, and Langdon, op. cit., pp. 262-264, Pl. XVI.

2 Op. cit., pp. 80-81, 133, Pl. X. See also Smith, Johnson, and Langdon, op. cit., pp. 270-272, 358, 359, Pl. XVIII.

3 Smith, E. A., The Cretaceous-Eocene contact: Jour. Geology, vol. 18, pp. 430-434, 1910. 

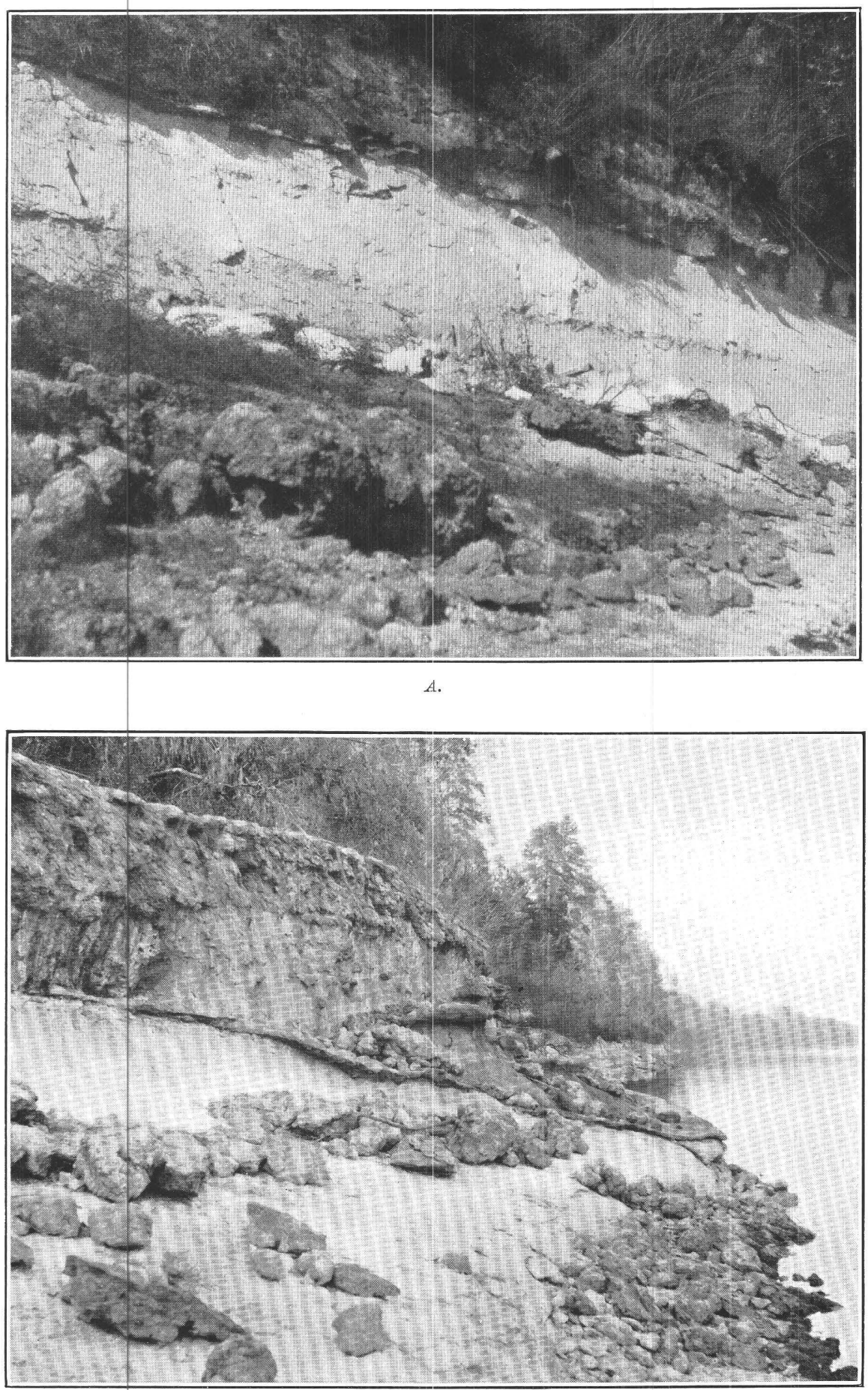

$B$.

CONTACT BETWEEN THE SELMA CHALK (UPPER CRETACEOUS) AND MIDWAY GROUP (EOCENE) AT OLD CANTON LANDING, ALABAMA RIVER, ALA.

The thin layer of quartzite at the base of the vegetation in $A$, and projecting conspicuously in $B$, marks the base of the Eocene. 


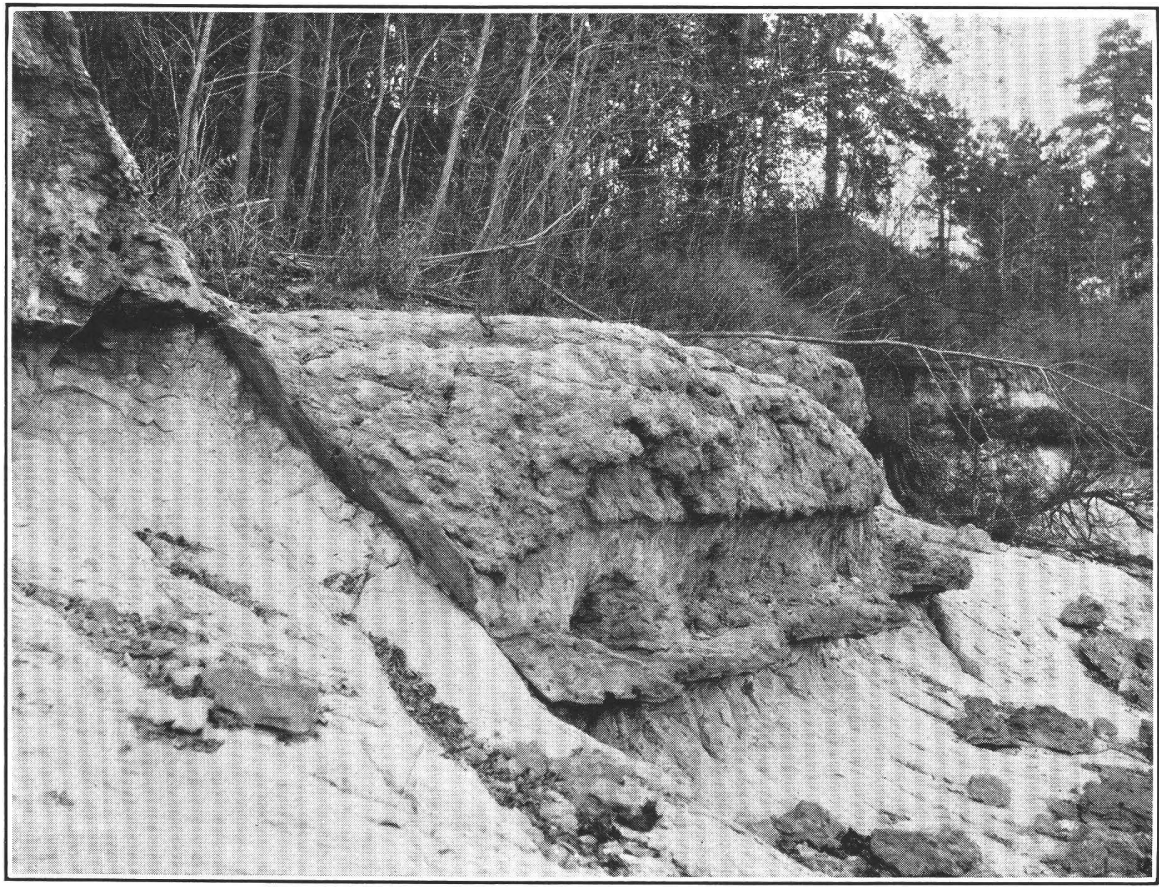

A. FAULT INVOLVING THE CRETACEOUS-EOCENE CONTACT AT OLD CANTON LANDING, ALABAMA RIVER, ALA.

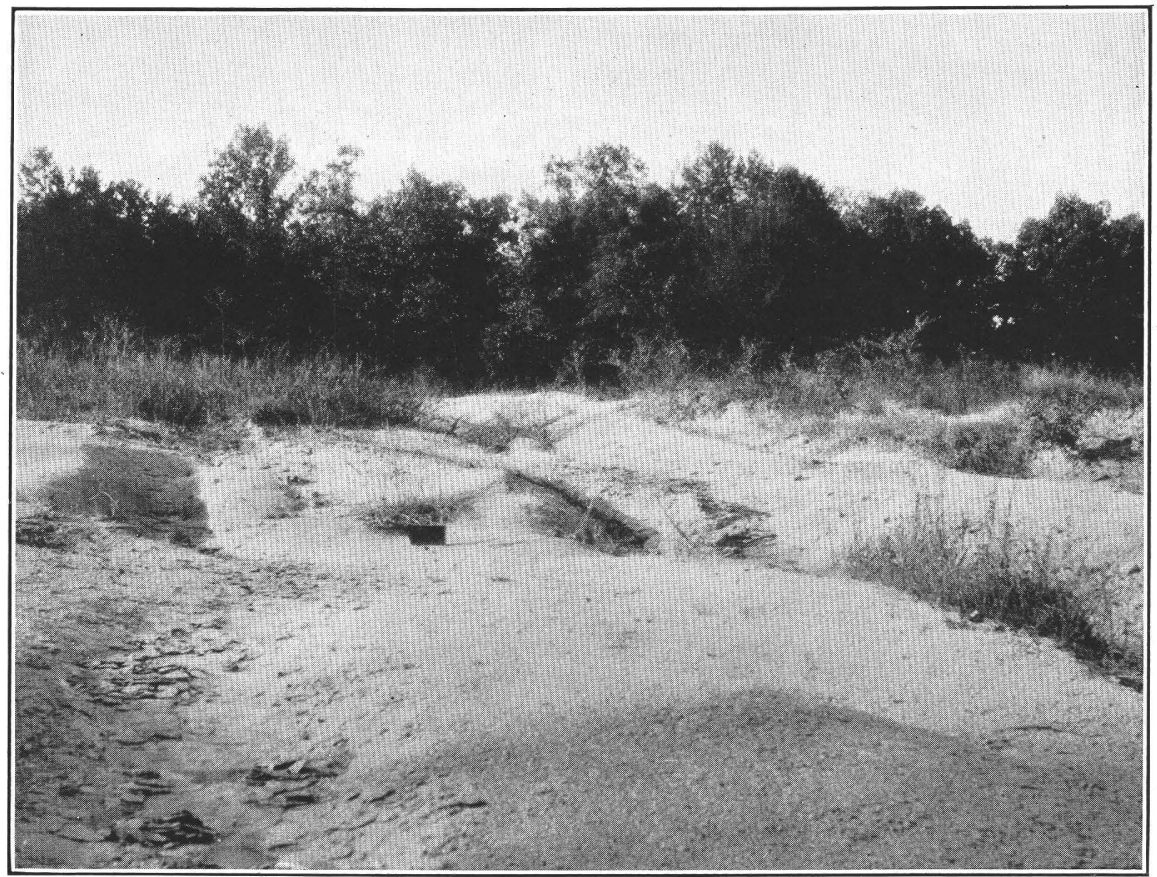

B. EXPOSURE EXHIBITING THE CRETACEOUS-EOCENE CONTACT ON MACON-DEKALB ROAD $7 \frac{1}{2}$ MILES SOUTH OF MACON, ALA.

Half a mile north of the crossing of Running Water Creek. On account of the similarity of the materials composing the uppermost Cretaceous (Selma) and the lowermost Eocene (Midway), the contact was determined only by the aid of the contained fossils. The basal Midway is here composed of reworked Selma chalk. The camera case rests on the contact. 
a short time to plane off the sea bottom and slightly cut down the fillings in the depressions. Soon, however, as the land continued to sink, the deposition of regular massive strata began, covering both the truncated elevations of the Sellma and the planed-off fillings in the depressions and producing the appearance of unconformity between the coarse fillings and the regularly bedded deposits above. The Cretaceous fossils found in these basal, lenslike sands and conglomerates were derived by mechanical mixture from the underlying Selma chalk.

The following fossils collected from the Midway at Moscow Landing by T. W. Vaughan and the writer were identified by C. Wythe Cooke:

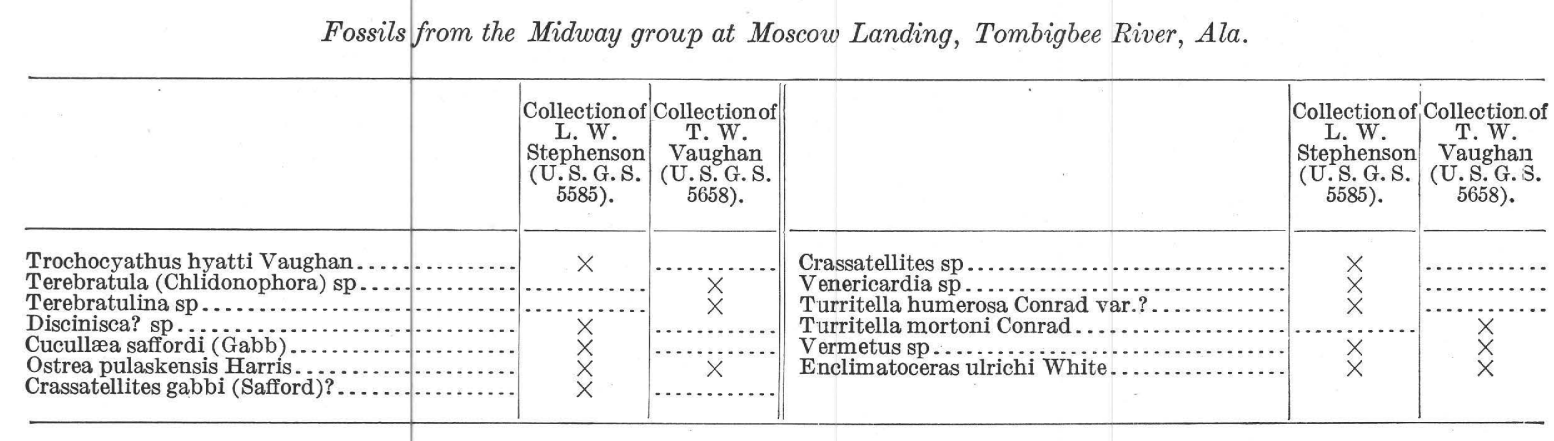

VICINITY OF LIVINGSTON, ALA.

Southwest of Livingston, Sumter County, Ala., the Midway (Eocene) rests unconformably upon the Selma chalk (Upper Cretaceous). Here, as at Moscow Landing, Old Canton Landing, and elsewhere in westcentral Alabama, strata of the Midway group were mistaken for the Ripley formation by Smith $^{1}$ and his assistants. The section represented by figure 16 expresses the writer's interpretation of an exposure on the Curls station road, half a mile southwest of the courthouse and just west of Sucarnochee W. E. Creek. In one of his trips to the locality (in 1910) the writer was accompanied by Dr. Smith, who concurred in this interpretation so far as it relates to the beds immediately below and above the contact. The details of the section are as follows:

Section on Curls station road southwest of Livingston, Ala.

Pleistocene (terrace deposit):

Feet.

$h$. Alluvial sand and clay.

Unconformity.

Pleistocene or Eocene:

g. Poorly exposed red ferruginous sand, grading down into coarse grayish sand (weathered phase of Midway or Pleistocene terrace deposit) $\ldots \ldots \ldots \ldots \ldots \ldots \ldots \ldots \ldots \ldots \ldots \ldots \ldots, 30$

1 Smith, E. A., Johnson, L. C., and Langdon, D. W., jr., Geologic map of Alabama, Alabama Geol. Survey, 1894. 


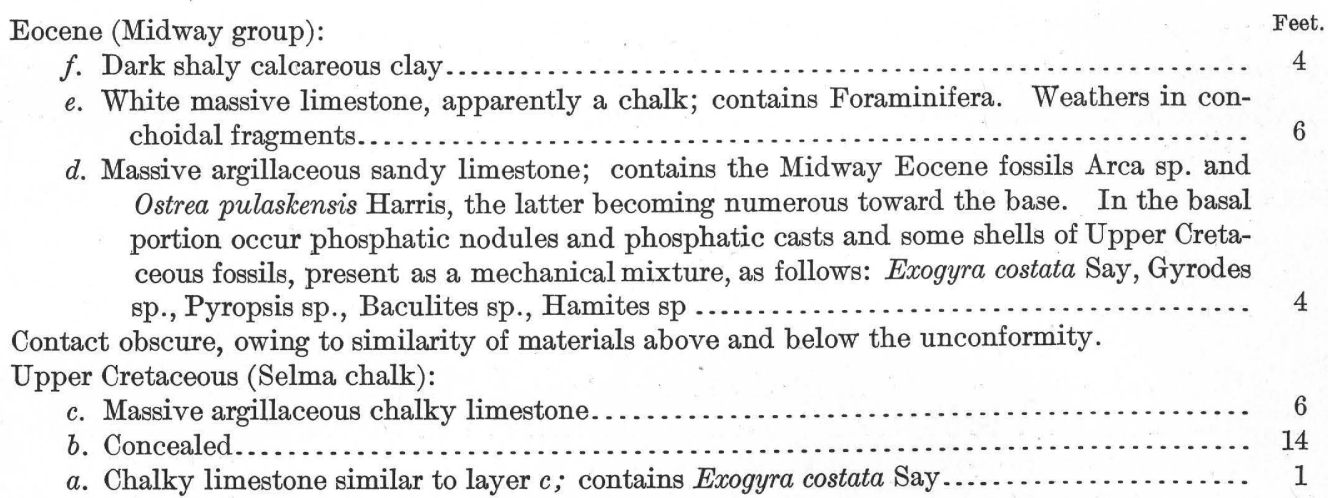

In company with Dr. Smith the writer made a trip by way of the Ramsey road from Livingston to Sumterville, a small village situated about 10 miles west of north of Livingston. After crossing Sucarnochee Creek within half a mile of the courthouse greenish clays - the

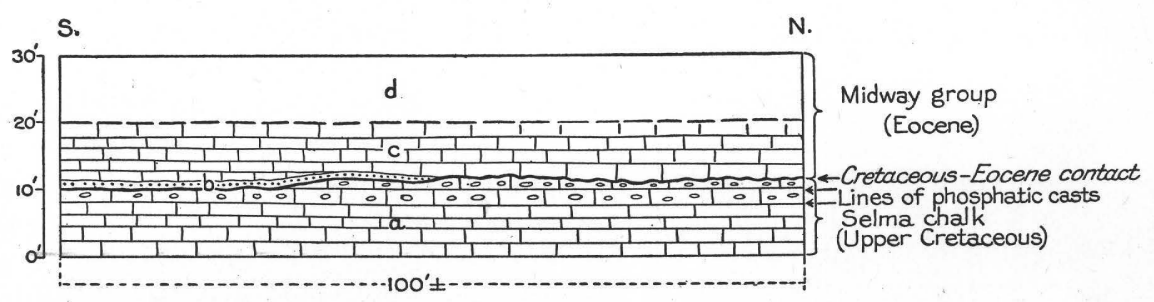

FIGURE 17.-Section showing Cretaceous-Eocene contact on Sucarnochee Creek 5 miles northwest of Livingston, Ala.

Sucarnochee clay of the Midway groupwere observed at intervals in road exposures for a distance of 4 or 5 miles. At a crossing of Sucarnochee Creek about 5 miles from Livingston the Cretaceous-

Eocene contact was observed where the stream had cut through the Eocene into the underlying Selma chalk. Figure 17 and the subjoined section show the relations of the deposits as observed. The thicknesses given in the section are approximate.

Section on Sucarnochee Creek 5 miles northwest of Livingston, Ala.

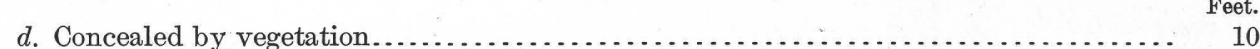

Eocene (Midway group):

c. Sandy limestone............................................. $8-10$

b. Coarse phosphatic sand with Cretaceous fossils, principally casts, mechanically derived from the underlying Selma chalk..................................... $1_{1}^{\frac{1}{2}}$

Sharp undulating contact.

Upper Cretaceous (Selma chalk):

a. Massive chalky limestone. A line of phosphatic casts of Cretaceous fossils is cut off in places by the unconformity, and a similar line of casts occurs a little lower in the

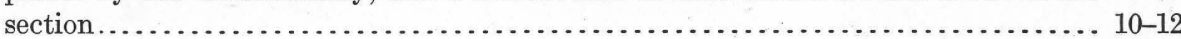

The Cretaceous-Eocene contact was observed at several places within 2 or 3 miles northwest of this locality, and at one place phosphatic casts of Cretaceous fossils mechanically included in the base of greenish clays (Sucarnochee clay) were noted. Sucarnochee clay was observed overlying the chalk to a point within 2 or 3 miles of Sumterville, the base of the clay gradually rising to the north and the clay finally feathering out south of Sumterville. These observations show that northwest of Livingston the Sucarnochee clay of the Midway group transgresses the older sandy and calcareous beds of the Midway, and south of Sumterville these beds are entirely overlapped and the clay rests directly upon the Selma chalk.

VICINITY OF SCOOBA AND WAHALAK, MISS.

The town of Scooba, Kemper County, Miss., is underlain by the Sucarnochee clay of the Midway group of the Eocene. Several poor exposures of greenish clays were observed in the streets and along the roads in the vicinity of the town, and a poor exposure of similar clay 
was noted along the Mobile \& Ohio Railroad, 1 mile north of town. Clays of the same character overlain by 5 to 10 feet of sand of undetermined age (probably Eocene) were observed at intervals along the Giles road for a distance of $2 \frac{1}{2}$ miles east of Scooba.

Three miles east of Scooba, where the road descends into a small valley, 6 feet of compact gray limestone belonging to the Selma chalk (Upper Cretaceous) appears in the roadbed and is overlain by 6 feet of residual sandy clay (Sucarnochee). From the chalk were obtained Exogyra costata Say, Gryphæa sp., Pecten venustus Morton, Plicatula sp. nov., and Lima sp. From this point to a place within half a mile of Giles, a small village about 6 miles east of Scooba, greenish clays overlain by a few feet of yellow sands, probably of Midway age, are exposed at intervals. Half a mile west of Giles the section represented in figure 18 was examined and found to contain the following beds:

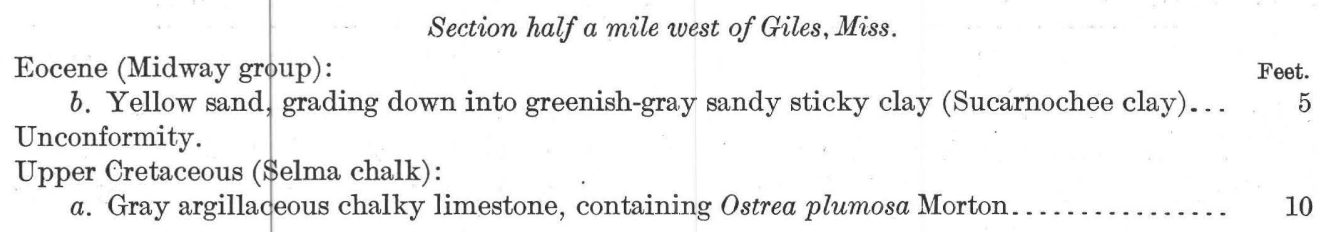

A few feet of sand corresponding to layer $b$ in this section appears in the public road to a point about $3 \frac{1}{2}$ miles east of Giles. In places this sand is underlain by 10 feet or more of greenish clays. A mile and a quarter east of Giles the Selma chalk appears in a bald spot and is overlain by the greenish clays. The chalk yielded Ostrea larva Lamarck and Gryphæa sp. The Selma is also exposed in a bald spot in the road about $3 \frac{1}{2}$ miles east of Giles, and

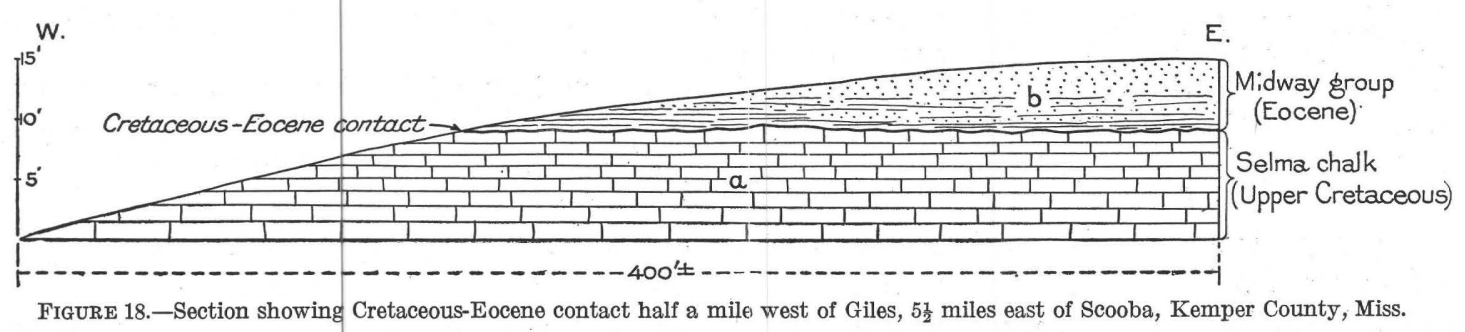

here were found Ostrea larva Lamarck and Ostrea plumosa Morton. Beyond this point to the east the Midway covering thins out and disappears and the surface materials consist of residual clays derived from the Selma chalk. About 10 feet of typical massive limestone of the Selma chalk is well exposed in the banks of a dry branch a short distance west of Ivy, Sumter County, Ala.

A trip was made from Scooba northward along a road which joins the Wahalak-Binnsville road in the Wahalak Creek valley about 6 miles from Scooba. Numerous exposures of greenish clay (Sucarnochee clay) of the Midway group were observed to the crest of the steep slope overlooking the Wahalak Creek valley. In the road leading down the slope the following section. is revealed:

Section in public road about 6 miles north of Scooba, Kemper County, Miss.

Eocene (Midway group):

Feet.

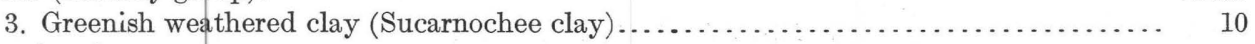

Unconformity.

Upper Cretaceous (\$elma chalk):

2. Massive chalky limestone, containing phosphatic casts of characteristic Upper Cretaceous fossils (Exogyra costata zone) in the upper 10 feet.................... 60

1. Very sandy limestone, constituting an arenaceous phase of the Selma chalk ......... 50

The Minnie Portis Spring is a quarter of a mile north of the post office at Wahalak, Kemper County, Miss., in a small branch which has cut its valley 25 or 30 feet below the upland level. The surface materials at the spring and in the immediate vicinity are the greenish clays belonging to the Sucarnochee clay, of the Midway group. This clay is closely underlain 
by fossil-bearing calcareous sandy clays, also belonging to the Midway, as shown by the following log of a shallow dug well in a small branch valley a few hundred yards east of the spring. The log is based in part on an examination of the materials thrown from the well and in part on oral statements by Mr. D. W. Portis.

Log of well near the Minnie Portis Spring, Wahalak, Miss.

[Fossils identified by C. Wythe Cooke.]

\begin{tabular}{|c|c|c|}
\hline . & Thickness. & Depth. \\
\hline 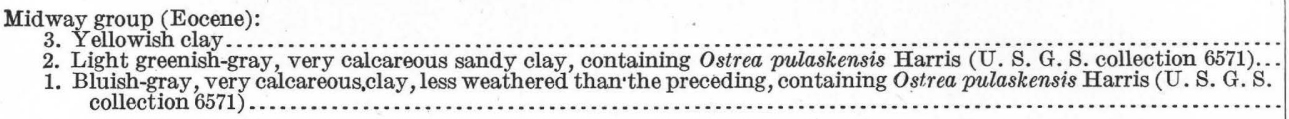 & Feet. $\begin{array}{r}5 \\
10 \\
6\end{array}$ & $\begin{array}{r}\text { Feet. } \\
5 \\
15 \\
21\end{array}$ \\
\hline
\end{tabular}

The fact that Hamulus onyx Morton, a Cretaceous fossil, was found associated with Ostrea pulaskensis Harris in layer 1 of the section doubtless shows that the Selma chalk closely underlies the Eocene and that this Cretaceous fossil was mechanically intermingled with the Eocene oysters.

Crider ${ }^{1}$ has noted the occurrence of Selma chalk along the bed of Wahalak Creek in the vicinity of Wahalak. He says:

Three miles north of Scooba the western border of the Selma chalk outcrop is seen in a series of hills forming the south bank of Wahalak Creek. The bottom of the creek here is about $1 \frac{1}{2}$ miles wide, with the steeper slope on the south side. The creek has channeled its bed into the white Selma chalk, which outcrops continuously throughout its course. The limestone occurs in the bed of the creek to a point $6 \frac{1}{2}$ or 7 miles northwest of Wahalak, but the overlying Porters Creek clay is present on the higher land on both sides of the creek.

On the low range of hills south of Wahalak Creek, beginning near the Mobile \& Ohio Railroad track and extending eastward, is a bed of sand rock 10 feet thick capping the tops of the hills. It is a coarse-grained sandstone cemented with lime carbonate and contains numerous little bivalve shells. It is similar to sandstone found 7 miles east of Sucarnoochee and doubtless represents the lowest beds of the Ripley formation.

Although the writer has not seen the calcareous sandstone mentioned in the second paragraph quoted, Crider's statement that it contains numerous small bivalve shells suggests that the rock is the basal calcareous portion of the Midway group, which in western Alabama carries large numbers. of Ostrea pulaskensis Harris, doubtless the fossil he noted.

On the geologic map accompanying Crider's report the Ripley formation (Upper Cretaceous) is represented as outcropping in a narrow area southwest of a northwesterly line passing through Scooba. The Selma, chalk is represented as outcropping northeast of the same line. The observations just recorded show that the Ripley is absent in this area and that the Midway group (Eocene) - probably the Sucarnochee clay-transgresses the Selma chalk for 5 to 10 miles to the northeast and east of Scooba.

Although on the map Crider represents Scooba as situated in the Cretaceous area, in his text ${ }^{2}$ he states that the town is in the Flatwoods area, which is underlain by the Midway group. This and other statements in Crider's text show that with the exception of his reference of the relatively thin calcareous and sandy basal beds of the Midway to the Ripley formation his interpretation of the stratigraphy of the area was correct.

\section{VICINITY OF SHUQUALAK, MISS.}

The Flatwoods, which are underlain by the Sucarnochee clay of the Midway group, are well developed immediately west of Shuqualak, Noxubee County, Miss. North of the town several poor exposures of Selma chalk (Upper Cretaceous) were observed in the Macon road, and in a field west of the road 1 mile north of town the Selma chalk is fairly well exposed in several bald spots; here were found the characteristic Upper Cretaceous fossils Ostrea plumosa 
Morton, Gryphæa vomer Morton, and Pecten venustus Morton. The town of Shuqualak is therefore situated about on the boundary between the Cretaceous and Eocene.

The Cretaceous-Eocene contact was found in the Macon-De Kalb road about half a mile north of the crossing of Running Water Creek and about 4 miles northwest of Shuqualak. The exposure is a bald spot on the southward-facing slope of a small branch and reveals the following section:

\section{Section in Macon-De Kalb road about $7_{\frac{1}{2}}$ miles south of Macon, Miss., and half a mile north of the crossing of Running} Water Creek.

Eocene (Midway group):

[Midway fossils identified by C. Wythe Cooke.]

3. Dark, greenish-gray compact calcareous clay containing Foraminifera and in the lower 3 to 5 feet large numbers of Ostrea pulaskensis Harris (U. S. G. S. collcction 6582) ...........

2. Moderately hard bluish-gray, somewhat sandy and argillaceous limestone. The upper 2 feet is a little harder than the lower portion and contains the following Eocene (Midway) species: Cucullæa saffordi Gabb?, Venericardia alticostata Conrad, Turritella mortoni Conrad (U. S. G. S. collection 6581). The basal portion weathers soft and a little shaly and contains Gryphæa vomer Morton?, probably a Cretaceous fossil derived mechanically

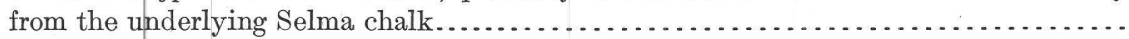

Unconformity indicated by some reworking of layer 1 in layer 2 and by borings in layer 1 filled by the darker materials of layer 2 .

Upper Cretaceous (\$elma chalk):

1. Gray, very hard, slightly sandy and argillaceous massive chalky limestone. Baculites sp. was found loose on the surface near the upper part of this bed.

\section{Feet.} 8

Owing to the close lithologic resemblance between layers 1 and 2 of the section the contact is inconspicuous and requires close scrutiny to discover it. A view of the exposure is given in Plate XIII, $B$.

\section{NORTHWEST OF MACON, MISS.}

The position of the Cretaceous-Eocene contact was approximately determined in an exposure on Horse Creek, a quarter of a mile north of Benjamin Taylor's store and 12 or 13 miles northwest of Macon, Noxubee County, Miss. The creek bank reveals 20 feet of massive, compact argillaceous, slightly siliceous chalky limestone belonging to the Selma chalk. The upper 2 feet of the rock is perforated with borings filled with gray calcareous clay. Weathered out in the soil on the slope just above the exposed beds of the Selma were found the following Eocene (Midway) fossils (identified by C. Wythe Cooke): A coral, Cucullæa saffordi Gabb?, Ostrea pulaskensis Harris, Turritella sp., Natica (2 species), Xenophora sp., Cylicna? (cast), and Pleuratoma? (cast) (U. S. G. S. collection 6572). The perforated portion of the chalk was doubtless immediately below the contact with the overlying Midway.

\section{STARKVILLE, MISS.}

The Selma chalk is exposed in gullies on the campus of the Agricultural and Mechanical College, near Starkville, Oktibbeha County, Miss., and these exposures have yielded 37 or more species of characteristic Upper Cretaceous fossils (from the Exogyra costata zone). A short distance north of the campus, in the Mayhew road about $1 \frac{3}{4}$ miles east of Starkville, the following section is exposed: 
The writer ${ }^{1}$ has shown that the chalky limestone revealed in gullies on the campus is a northward-extending tongue of the Selma and is stratigraphically higher than a long tongue of the Ripley formation which extends southward from Chickasaw County and apparently pinches out in Noxubee County. W. N. Logan ${ }^{2}$ correctly referred layer 2 of the Mayhew road section to the Ripley formation, but he regarded the sand as overlying the limestone (layer 3 ) and as constituting an outlier of the Ripley.

Starkville is located on the Cretaceous-Eocene contact, which is exposed in cuts of the Illinois Central Railroad southwest of the station. The following succession of strata appears in a cut a quarter of a mile southwest of the station:

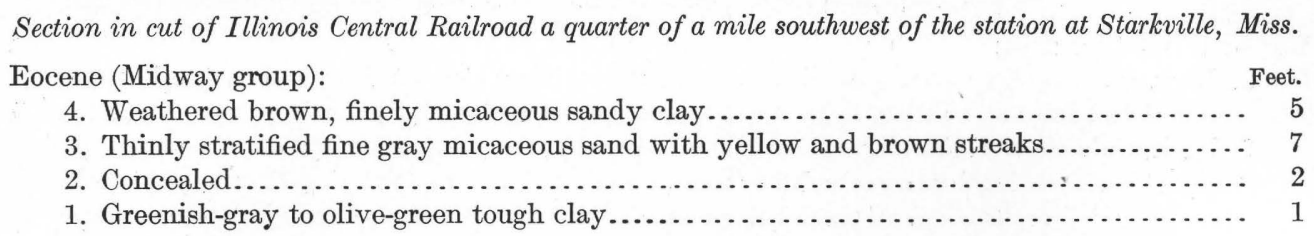

The beds described in the section were referred by $\operatorname{Logan}^{3}$ to the Lafayette formation, but the writer does not hesitate to correlate them with the Midway group of the Eocene. They constitute the eastward feather edge of the Midway, the main outcrop of which begins within less than $1 \frac{1}{2}$ miles southwest of Starkville along this railroad.

From the cut southwestward the railroad track descends a rather steep grade, and half a mile from the station 6 feet of massive chalky limestone (Selma chalk) overlain by 2 feet of yellow residual clay is exposed in a shallow cut. A cut $1 \frac{1}{2}$ miles southwest of the station reveals 4 or 5 feet of grayish to greenish-gray hard sandy residual clay, probably a weathered phase of the Sucarnochee clay of the Midway group (Eocene). The actual contact between the Cretaceous and Eocene was not observed in this vicinity.

VICINITY OF HOUSTON, MIss.

A cut of the Mobile \& Ohio Railroad (Houston branch) at Houston, Miss., reveals the following section:

Section in cut of Mobile \& Ohio Railroad at Houston, Miss.

Eocene (Midway group?): Feet.

4. Residual yellow sandy ferruginous clay $. . \ldots \ldots \ldots \ldots \ldots \ldots \ldots \ldots \ldots \ldots \ldots \ldots . .7$

3. Gray massive, compact calcareous glauconitic, somewhat argillaceous, finely micaceous

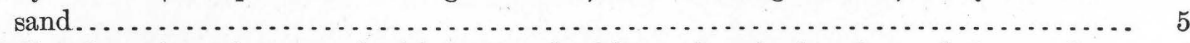

2. Yellow loose ferruginous sand with scattered white grains of arkose?, poorly exposed.... 4

Sharp contact.

Upper Cretaceous (Selma chalk):

1. Gray massive, very calcareous glauconitic, finely sandy clay resembling an impure phase

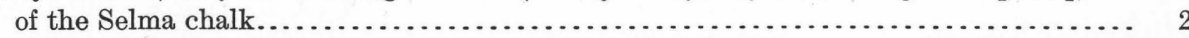

Baculites sp., probably derived from layer 1 of the section, was found on the dump at the end of the cut.

The Cretaceous-Eocene contact is exposed on the old Houlka road $1 \frac{1}{2}$ miles north of Houlka, as described in the following section:

Section in the old Houlka road $1 \frac{1}{2}$ miles north of Houston, Miss.

Eocene (Midway group): $\quad$ Feet.

7. Yellowish hard calcareous glauconitic sandstone. ...................... 7

6. Dark-gray argillaceous glauconitic compact calcareous sand, containing Ostrea pulaskensis

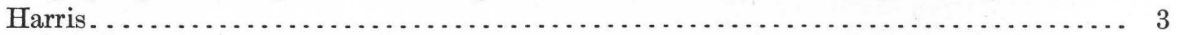

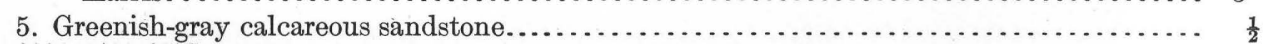

4. Compact red and yellow fine micaceous sand . . . . . . . . . . . . . . . . . . 1

3. Reddish, rather coarse sandstone. . . . . . . . . . . . . . . .

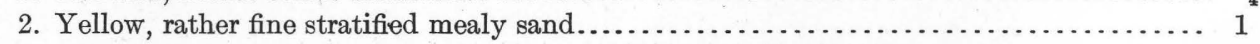

Sharp contact.

Upper Cretaceous (Selma chalk):

1. Compact gray argillaceous limestone............................... 2

1 U. S. Geol. Survey Prof. Paper 81, p. 17, Pl. IX, 1914. $\quad{ }^{2}$ Mississippi Agr. and Mech. Coll. Bull., vol. 1, No. 2, p. $30,1904 . \quad{ }^{3}$ Idem, p. 35. 


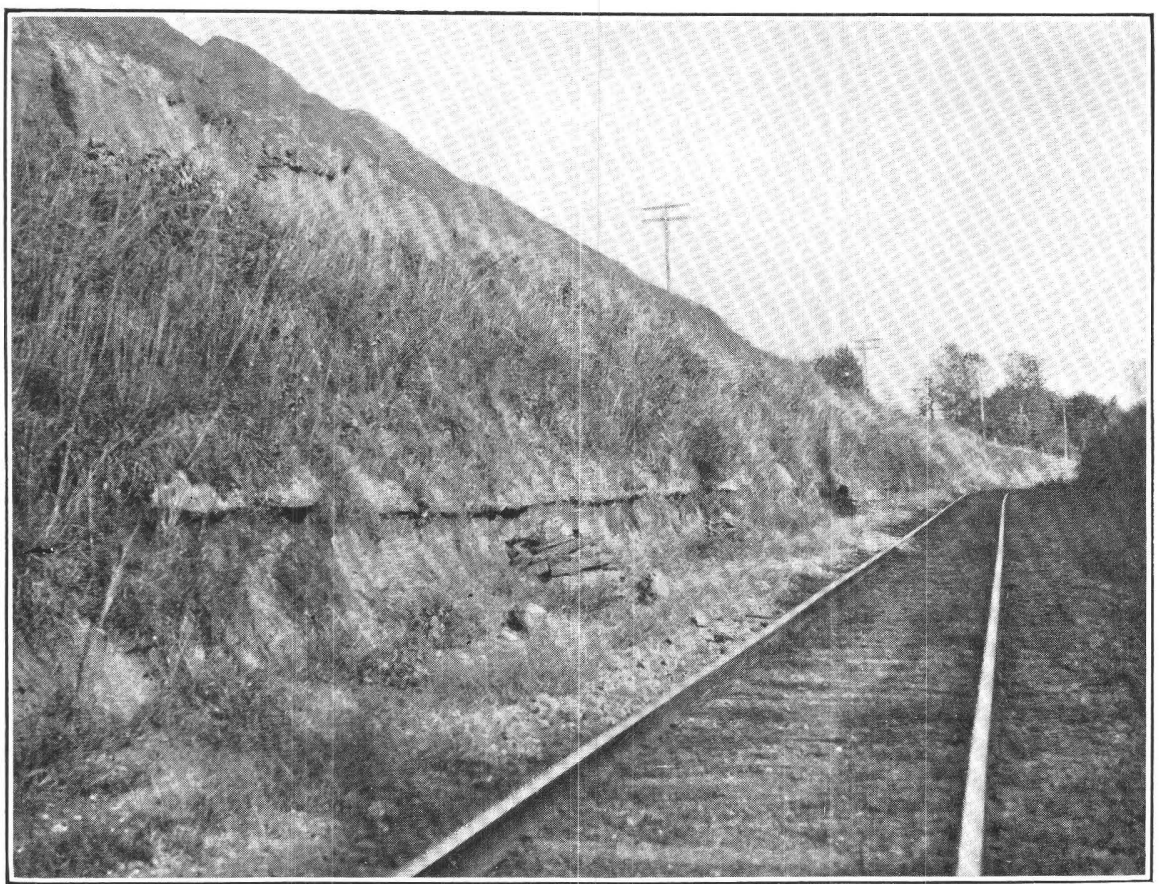

A. CRETACeous-eocene CONTACT in CUT OF ST. LOUIS \& SAN FRANCISCO RAILROAD 1 MILE EAST OF NEW ALBANY, MISS.

The contact is beneath the indurated layer.

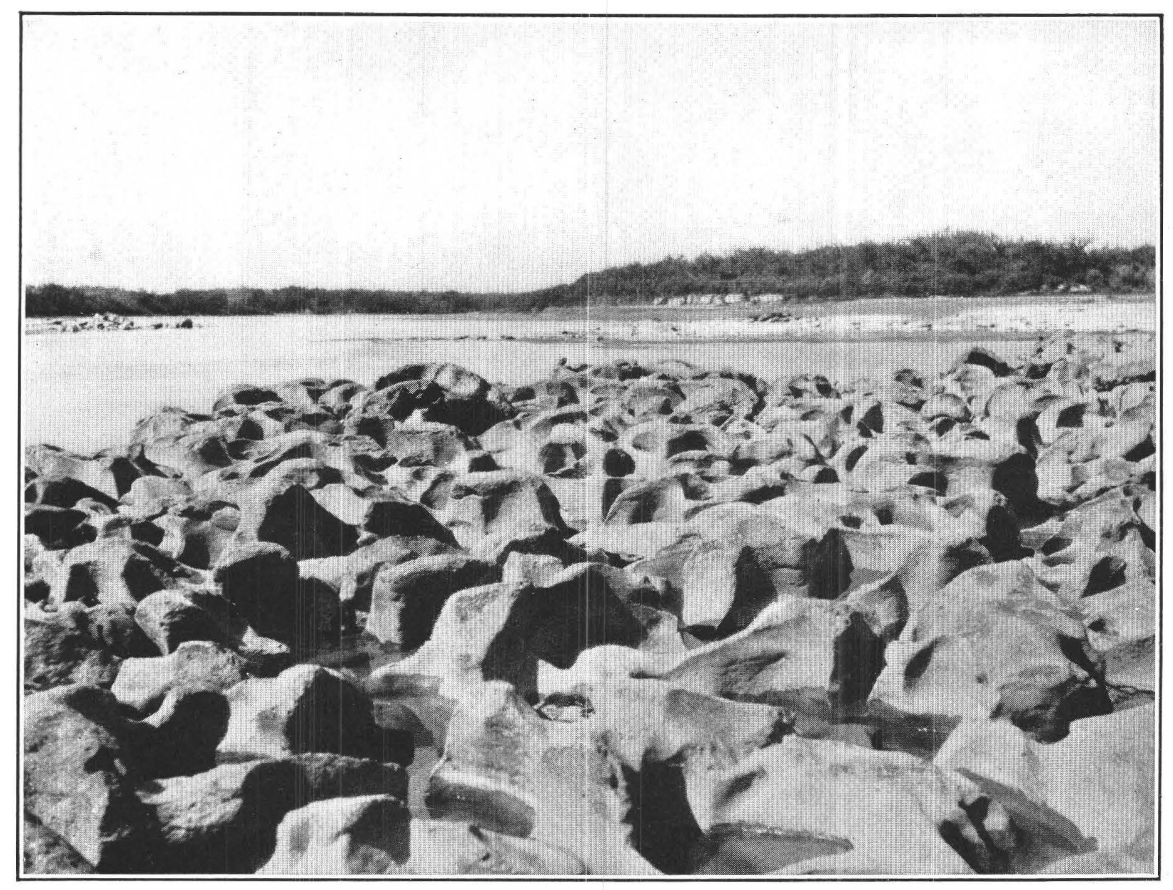

B. POTHOLES IN BASAL LIMESTONE OF THE MIDWAY FORMATION ON THE RIO GRANDE 1 MILE BELOW WHITE BLUFF, MAVERICK COUNTY, About 4 miles above the Webb County line. 

A cut of the New Orleans, Mobile \& Chicago Railroad 3 miles north of Houston reveals about 8 feet of light-greenish to yellowish nodular limestone containing large numbers of $O$ strea pulaskensis Harris (U.S. G. S. collection 5587; identified by C. Wythe Cooke) in the upper 4 feet, overlain by 8 feet of tough yellowish and greenish clay, probably residual from the limestone; this rock belongs to the Midway group of the Eocene.

In the main public road 1 to $1 \frac{1}{2}$ miles south of Houston reddish and yellowish ferruginous sands and clays, probably belonging to the Midway group of the Eocene, were observed overlying with a sharp unconformity the massive argillaceous chalky limestone of the Selma chalk, which in places contains numerous characteristic Upper Cretaceous fossils (Exogyra costata zone).

The weathered representatives of the sands and clays of the Midway at Houston extend eastward above the Selma, capping the tops of the hills for a distance of at least 2 miles.

\section{VICINITY OF PON'TOTOC, MISS.}

A deep cut of the New Orleans, Mobile \& Chicago Railroad about half a mile south of the station at Pontotoc, Miss., reveals nearly 50 feet of reddish, yellowish-brown, and grayish glauconitic sands belonging to the Ripley formation (Upper Cretaceous). In a stratum of massive coarse yellowish-brown glauconitic sand, 15 to 20 feet below the top of the section, the following poorly preserved characteristic Upper Cretaceous fossils (Exogyra costata zone) were recognized: Exogyra costata Say, Veniella conradi (Morton), Cardium tippanum Conrad. About 30 feet of similar sands are exposed in a ballast pit along the same railroad about $2 \frac{1}{2}$ miles northwest of Pontotoc.

From a point a short distance west of the old right of way of the New Orleans, Mobile \& Chicago Railroad, which lies a mile or more west of the present right of way, southwestward for several miles the public road passes over light-yellowish clays which are probably weathered residual materials derived from the Sucarnochee clay of the Midway group.

The Cretaceous-Eocene contact was not found well exposed in the vicinity of Pontotoc, but the data just given indicate that the boundary lies about a mile west of the railroad station.

VICINITY OF NEW ALBANY, MISS.

The town of New Albany, Union County, Miss., lies about a mile west of the outcrop of the Cretaceous-Eocene contact. The relations of the two series are well exhibited in a cut of the St. Louis \& San Francisco Railroad 1 mile east of New Albany. (See Pl. XIV, A.)

Section in cut of St. Louis \& San Francisco Railroad 1 mile east of New Albany, Miss.

Eocene (Midway group): $\quad$ Feet.

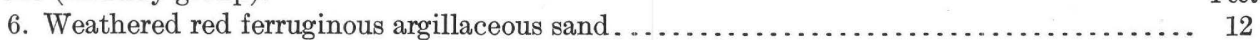

5. Yellowish-brown ferruginous sand with masses of small irregular to roundish iron concretions, apparently arranged in lenses...................................... 7

4. Weathered yellowish-brown ferruginous sand . . . . . . . . . . . . . . . . . . . . . 9

3. Yellow massive, somewhat sandy limestone, containing the Midway species Venericardia sp. and Turritella mortoni Conrad (U. S. G. S. collection 6573; identified by C. Wythe Cooke). Mechanically included in the base of the limestone were found the following Upper Cretaceous fossils: Pecten argillensis Conrad, Crassatellites sp., and Cardium



2. Yellow, very calcareous sand .................................... Upper Cretaceous (Ripley formation):

1. Dark-gray massive, very compact argillaceous sand with a few poorly preserved specimens of Exogyra costata Say, Pecten argillensis Conrad, and Baculites sp...................

SOUTHWESTERN TEXAS.

MAVERICK COUNTY.

Roemer ${ }^{1}$ in 1848 discussed the geographic position of the Cretaceous-Eocene contact in Texas as follows:

An ideal line drawn from Presidio de Rio Grande on the Rio Grande in a northeast direction, and crossing the San Antonio River at the town of the same name, the Guadalupe at New Braunfels (the German settlement), the Colorado

${ }^{1}$ Roemer, Ferdinand, Contributions to the geology of Texas: Am. Jour. Sci., 2d ser., vol. 6, p. 21, 1848. 
at Austin, the Brazos at the falls of this river, the Trinity below its forks, and reaching from there to the Red River in the same northeast direction, divides the Tertiary strata and the diluvial and alluvial deposits (of the level and "rolling" part of the country) from the Cretaceous and older formations (of the hilly and mountainous sections).

In 1889 Penrose $^{1}$ stated, with reference to the Cretaceous along the Rio Grande:

It may be said, however, that Cretaceous fossils have been found at Eagle Pass, and from there down the river to the Webb County line are found great quantities of ammonites and other fauna of that epoch. In fact, it is not until we reach a point 3 miles below the northwest corner of Webb County that true Tertiary (or Laramie) forms are found. Supposing the Cretaceous and Tertiary parting to cross the river at this point, we would do away with the much mooted question of the westerly extension to Las Moras Creek, above Eagle Pass, as drawn by Loughridge, Conrad, and others, and the slight deflection to the west could easily be accounted for by the supposition of an embayment on the Rio Grande at the time of the deposition of these strata, similar to that which existed at the same time on the Mississippi. Roemer makes the line of parting across the Rio Grande at Presidio de Rio Grande, 10 miles above Laredo, while Schott refers to all the country from the mouth of the Pecos to the Gulf of Mexico as the "Cretaceous basin of the Rio Bravo" (Rio Grande). It seems probable now, so far as can be judged without a further study of the fossils, that Roemer was nearer right than the others, and that, as has been pointed out by Hill, the line as drawn by Conrad was based on certain Tertiary fossils which had been misplaced in the collection.

At a point 5 miles below Las Cuevas Creek are the Angostora Rapids. These are caused by a reef of oyster shells, of the same kind as mentioned above, which run across the river and are covered on either bank by the same gray or buff sandstones. For 16 miles below here, by river, we find almost uninterrupted outcrops of similar deposits of desiccated and indurated sands and clays, containing many ammonites and other forms similar to those found at the Cretaceous exposure in Anderson County. At this point we come to what is known as Las Isletas. The river is a half mile wide and very shallow. It is full of small islands, consisting of sand bars and covered by mesquite and cane. The bottom of the river is rocky and causes almost continuous rapids for 5 miles.

For 12 miles below Las Isletas, and to a point 3 miles below the north line of Webb County, we see many outcrops of a formation similar to those already described and with similar fossils. But here the fauna changes and the character of the strata becomes more glauconiferous.

Dumble $^{2}$ in 1892 discussed the same section as follows:

From this point [10 miles below Eagle Pass] to the falls of the Rio Grande, just above the Webb County line, the exposures are but repetitions one of another-brown, buff, blue, or green clays, with sandstones, sometimes friable and sometimes so indurated as to be semiquartzites. Abundant fossils, consisting of ammonites (Placenticeras), oysters, and gastropods, are found. The rapids (or falls of the Rio Grande), which continue almost to the line between the two counties, are formed by the edges of some of these ammonite-bearing beds as they pass below water level. From this point to Webb Bluff, a distance of 3 miles, no fossils were found; but there was no change in the lithologic character of the rock materials, nor could the clays at the base of the Webb Bluff section be distinguished in any way from those observed at the rapids above.

Gravel.

Webb Bluff section.

Sandstone, white and glistening, with mica and some little iron; calcareous sandstones; clay, with cannon-ball concretions; and small seam of grahamite............................ 30

Greensand marls with many Tertiary fossils; nodules of carbonate of lime; specks of glauconite .. 7-8

Stiff, plastic dark-greenish or blue clay, jointed.............................. 10

We have, therefore, only 3 miles in which there can be any room for deposits intermediate between strata containing fossils of recognized and decisively marine Cretaceous forms and those containing marine Eocene forms. The average dip does not exceed 100 feet per mile, and we saw nothing in any of the exposures on either bank of the river in this space to indicate a change until we reached Webb Bluff itself. The entire appearance of the upper portion of this bluff was so different from that of the materials we had been examining for the three previous days that it was remarked even before we landed. Tex.:

Vaughan $^{3}$ in 1900 said, with reference to the location of the contact in Maverick County,

It is at about the point where the foregoing section was made [ $4 \frac{1}{2}$ miles above mouth of San Ambrosia Creek] that the southern fence of the India ranch pasture is reached. This fence is, according to the statements of a colored cowboy, between three-fourths of a mile and a mile above the Webb-Maverick county line. Just beyond this fence, within the India ranch pasture, hematitic concretions containing Venericardia alticostata Conrad and a species of Glycymeris (Pectunculus) of the type of $G$. staminea (Conrad) were found in the clays. A little farther up the river was a large mass of sandstone resting on the clays and containing beautiful specimens of Turritella mortoni. The sandstone was so hard that no attempt was made to get the shells out.

1 Penrose, R. A. F., jr., Geol. Survey Texas First Ann. Rept., pp. 38-41, 1889

2 Dumble, E. T., Geol. Soc. America Bull., vol. 3, pp. 228, 229, 1892.

${ }_{3}$ Vaughan, T. W., Reconnaissance in the Rio Grande coal fields of Texas: U. S. Geol. Survey Bull. 164, pp. 38-39, 53, 1900. 


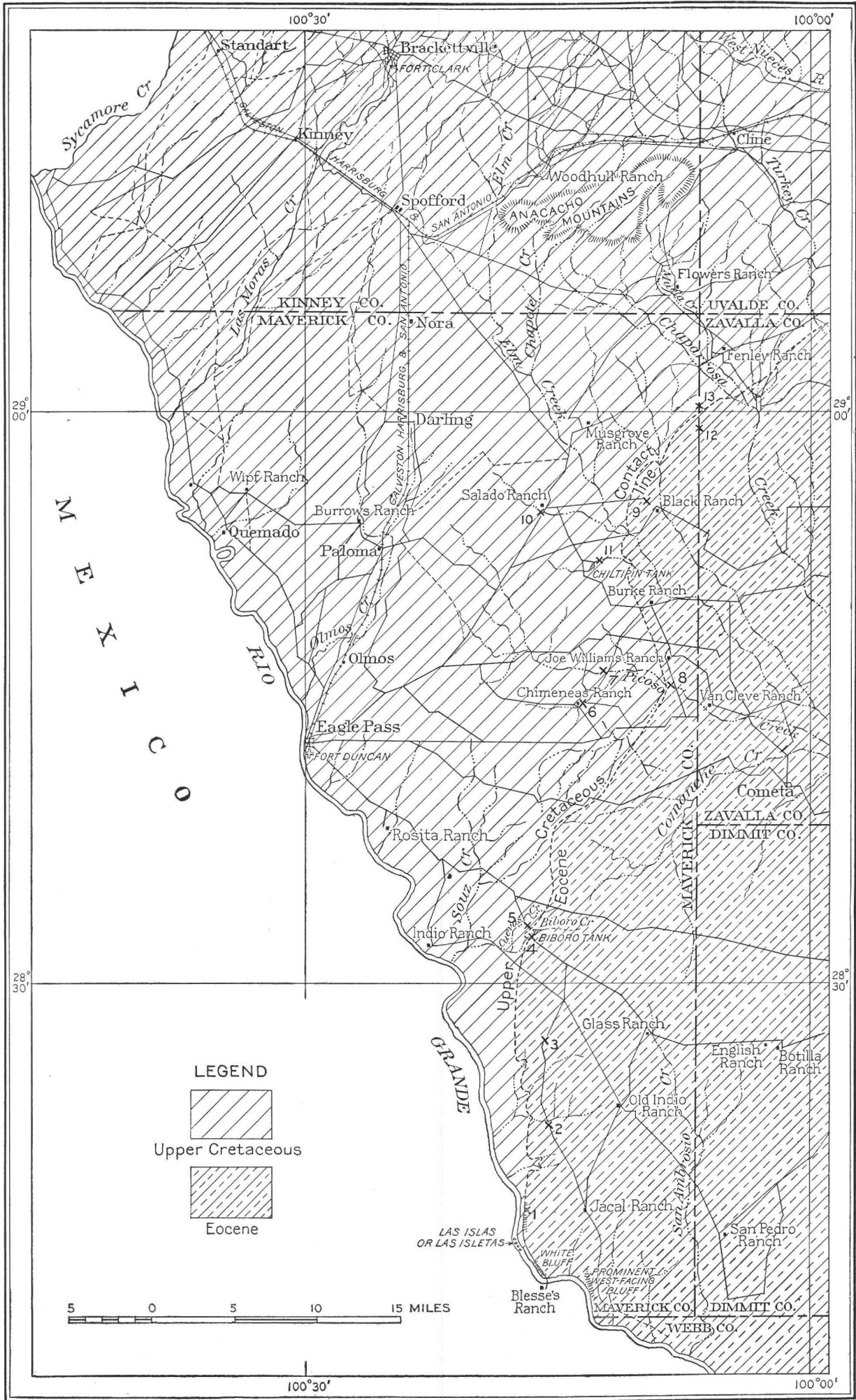

MAP OF MAVERICK COUNTY, TEX., SHOWING THE APPROXIMATE TREND NORTHWARD THROUGH THE COUNTY. 

From $1 \frac{1}{2}$ to 2 miles above the fence referred to the thinly bedded sands and clays are seen to be underlain by thinly bedded sands, passing downward into thin ledges of soft sandstone.

This has carried the Eocene to a point at least 2 to 3 miles above the Webb-Maverick county line. The horizon of the Eocene is Midwayan. The following five species of fossils were collected [list revised by Mr. Vaughan]:

Turritella mortoni Conrad.

Ostrea crenulimarginata Gabb.

Glycymeris (Pectunculus) sp. indet.

Venericardia planicosta Lamarck (var.).

Venericardia perantiqua Conrad?.

Harris has identified from the Dumble-Penrose collection made 3 miles below the Webb-Maverick county line fossils that are probably Midwayan, lower Eocene, but the writer has been unable to obtain a list of the species found there. Harris ${ }^{1}$ says: "We should note the peculiar fauna, Midway, in part at least, found by Dr. White 18 miles southeast of Eagle Pass. It consists of Cucullæa macrodonta (perhaps saffordi), Pectunculus, and Venericardia. The shelly matter of these species is completely crystallized. The matrix was evidently a calcareous light sand or sandstone."

*

From the foregoing discussion of the Eocene-Cretaceous contact and from the sections of the Eocene it has already been made evident that there is not yet sufficient data to trace accurately the boundary between the Cretaceous and the Eocene. This boundary crosses the Rio Grande some miles, at least 4 or 5 , above the north line of Webb County; it runs northeastward 1 or 2 miles northwest of India ranch, and passes some 16 miles west of Carrizo Springs. From here the boundary continues northeastward and crosses the Nueces River about the north line of Zavalla County. It continues north of east to the Frio River, crossing that stream 2 miles below the Engelmann ranch, and 5 miles, in a straight line, north of the south line of Uvalde County. The last-mentioned point is the only absolutely determined contact. The others are supposed or inferred from the data at hand.

In 1903 Dumble ${ }^{2}$ took exception to Vaughan's statement in regard to the exact geographic position of the exposures from which he (Vaughan) obtained certain Eocene fossils and endeavored to show that these exposures were probably close to Webb Bluff.

Additional statements with reference to the Cretaceous-Eocene contact along the Rio Grande were made by Dumble ${ }^{3}$ in 1911 as follows:

Major Emory, in the first part of the Boundary Survey report, on page 68, gives a description of Las Isletas and the falls of the Rio Grande, with a full-page illustration opposite. This description would indicate that the falls of the Rio Grande and Las Isletas were the same. The truth is that Las Isletas is located about the mouth of Castano Creek, while the falls are some 4 miles lower down the river, just below the mouth of Caballero Creek.

It will thus be seen that our collections were made from localities directly on the line of travel of the Boundary Survey party, and it seems highly probable that the original specimens described by Conrad were in reality obtained from these same beds.

The horizon is the uppermost portion of our Escondido beds. The fossils are among the latest Cretaceous forms of which we have any present knowledge in this region.

The Cretaceous-Eocene contact is well shown 3 miles below Toro Colorado, just above the falls of the Rio Grande and on Caballero Creek.

The only other records I can find of any of these forms are as follows:

Prof. G. D. Harris, in "The Tertiary geology of southern Arkansas," gives a list of fossils collected by Dr. C. A. White, in 1887, at his camp 18 miles southeast of Eagle Pass, Tex., which were supposed to be basal Tertiary. Among these there is a Cardium which Mr. Harris figures both in this paper and later with his Midway fauna, "Bulletin of American Paleontology, No. 4," without giving it a specific name.

This camp was probably at the Eagle Pass-Laredo road crossing near the junction of Cuevas and Pena creeks, and on or near the Cretaceous-Tertiary contact. The Cardium is unquestionably the Cardium congestum of Conrad, while the other forms named by Prof. Harris are from the overlying Midway.

The fossils obtained by White 18 miles southeast of Eagle Pass, as determined by Harris, ${ }^{1}$ are Cucullæa macrodonta (Whitfield), Pectunculus sp., Venericardia sp., and Cardium sp.

Dumble, in the paper published in Science just cited, does not state the position of the fossil localities described with reference to the Webb County line, but Las Isletas (or Las Islas), which he says is located about the mouth of Castano Creek, is in Maverick County, approximately 7 miles by the river above the Webb County line; according to his further statement, this would place the intersection of the Cretaceous-Eocene contact with the Rio Grande about 3 miles above instead of 3 miles below the county line.

1 Harris, G. D., The Midway stage: Bull. Am. Paleontology, vol. 1, pp. 127-128, 1896

2 Dumble, E. T., Geology of southwestern Texas: Am. Inst. Min. Eng. Trans., vol. 33, pp. 931, 932, 1903.

${ }^{3}$ Dumble, E. T., Rediscovery of some Conrad forms: Science, new ser., vol. 33, p. 971, 1911.

$37183^{\circ}-15-12$ 


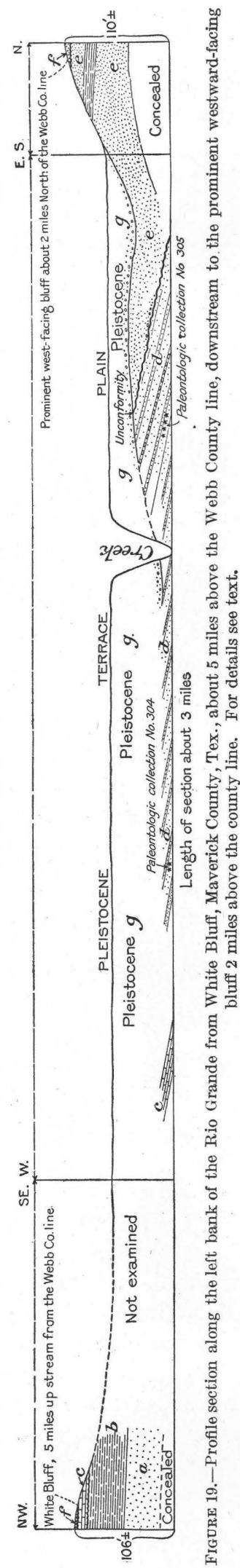

In the autumn of 1912 the writer made investigations in Maverick County which resulted in the exact determination of the Cretaceous-Eocene contact along the river and the approximate determination of the outcrop of the contact northward through the county. (See Pl. XV.)

The accompanying profile section (fig. 19) shows roughly the structure and stratigraphic relations of the beds exposed between White Bluff, 5 miles above the Webb County line, and a prominent westward-facing bluff about 2 miles above the county line. The succession is as follows:

Section on Rio Grande below White Bluff, Maverick County, Tex.

Pleistocene (terrace deposit):

g. Gray massive loamy sand, with a band of pebbles along the base in places ............................... 20-50

Unconformity.

Pliocene or Pleistocene (Uvalde formation):

$f$. Thin surficial covering of gravel, in places cemented with a white spongy matrix of lime.................... $3-4$

Unconformity.

Eocene:

Sandstone of Midway or Wilcox age:

$e$. Irregularly bedded medium to coarse grained sandstone, with subordinate thin laminated layers of gray clay; includes some thick, relatively short massive lenses of sandstone, but in the main the rocks are crossbedded. Vegetable particles and small pieces of lignite are common. At one place there is a basal conglomerate 2 or 3 feet thick composed chiefly of pebbles of iron carbonate derived from the concretions

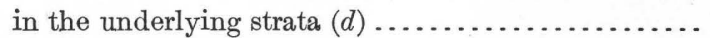
Unconformity; sharp contact, undulating slightly.

Midway formation:

d. Massive dark-gray (light gray or greenish gray where weathered), more or less argillaceous and glauconitic, slightly indurated sand, with harder ledges at intervals of 5 to 15 feet. Subordinate layers of shaly clay were noted. Concretions of iron carbonate are common in the upper 50 feet and in places occur in layers. Fossils were found at the points indicated (field Nos. 304 and 305 ; see lists on p. 173)............ 150-200

c. Gray fossiliferous limestone in layers 1 to $1 \frac{1}{2}$ feet thick, interbedded with greenish-gray sand in layers 1 to 2 feet thick; becomes sandy and glauconitic in the basal portion, which also contains some balls and fragments of clay derived from the underlying Cretaceous strata. Fossils obtained from the limestone are enumerated on

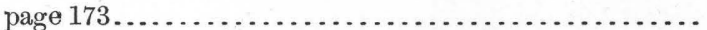

Unconformity; contact sharp and undulates slightly.

Upper Cretaceous (Escondido formation):

b. Greenish-gray shaly clay with crystals of gypsum; contains a few interbedded lenses of fine greenish-gray sandstone; grades downward into next layer.....................

a. Greenish-gray glauconitic sand, partly indurated to nodular layers; contains numerous Upper Cretaceous fossils (see list on p. 173)

At White Bluff (see map, Pl. XV), at the upstream end of the profile section, the Cretaceous-Eocene contact is clearly exposed for a distance of several rods (see PI. XVI) and lies 90 or 95 feet above the river. At the upstream end of the prominent part of the bluff the base of the Eocene limestone is faulted down 25 or 30 feet below the position shown in the photograph. The section is as follows: 


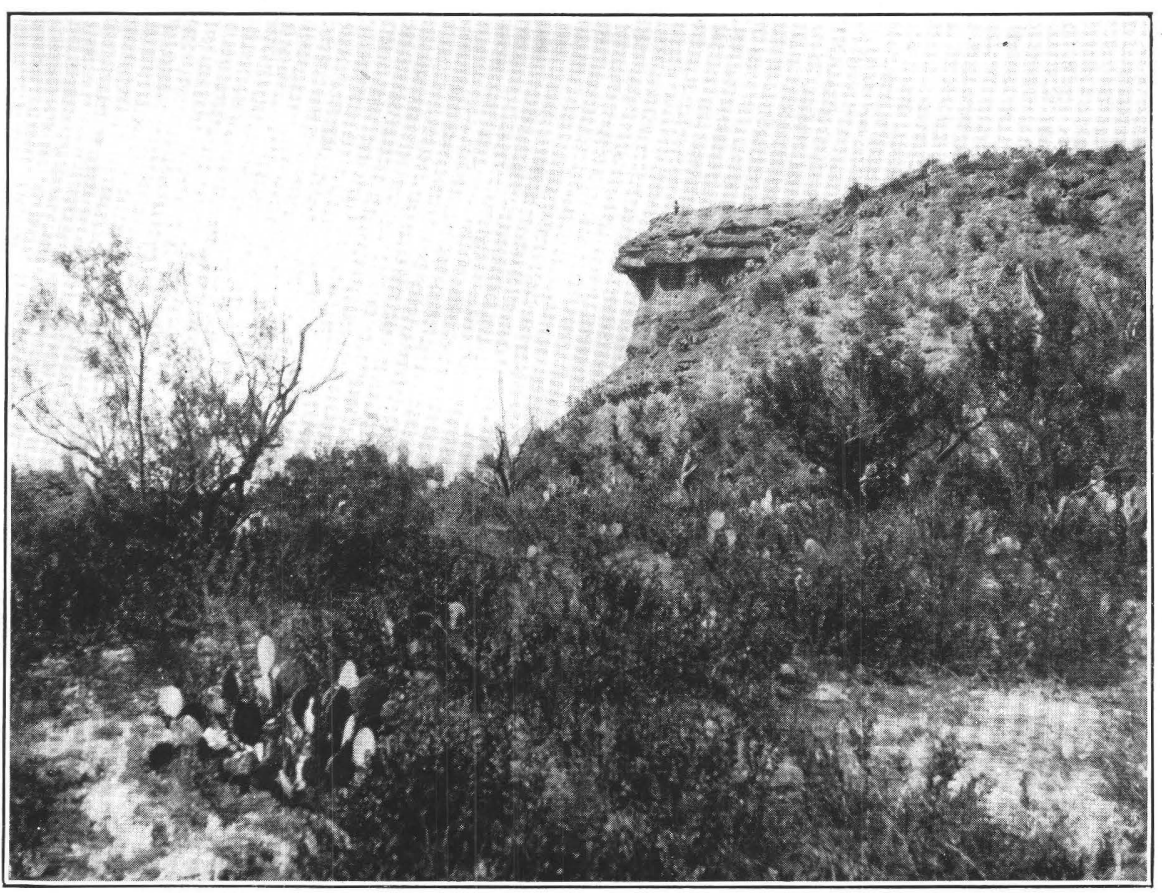

$A$.

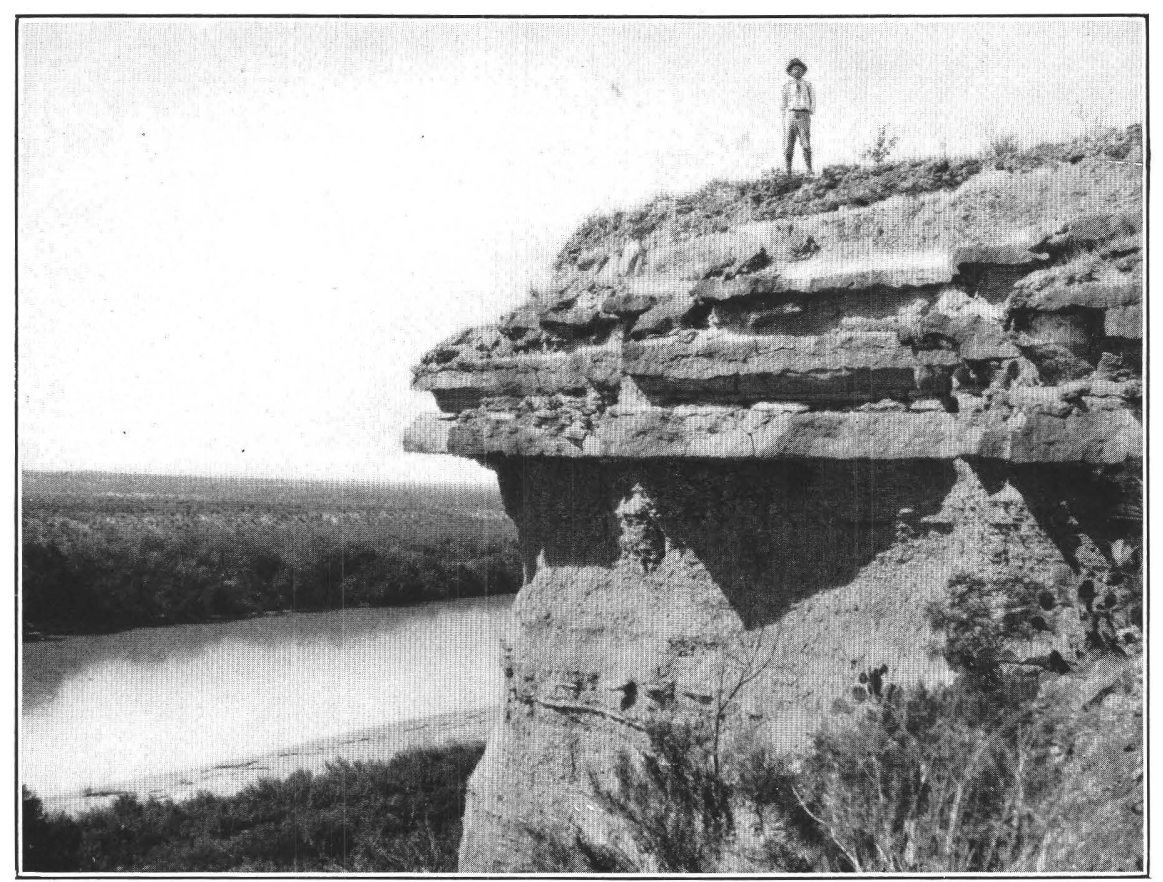

$B$. CRETACEOUS-EOCENE CONTACT ON THE RIO GRANDE AT WHITE BLUFF,
MAVERICK COUNTY, TEX.

About 5 miles above the Webb County line. The contact lies at the base of the projecting ledge of rock. 


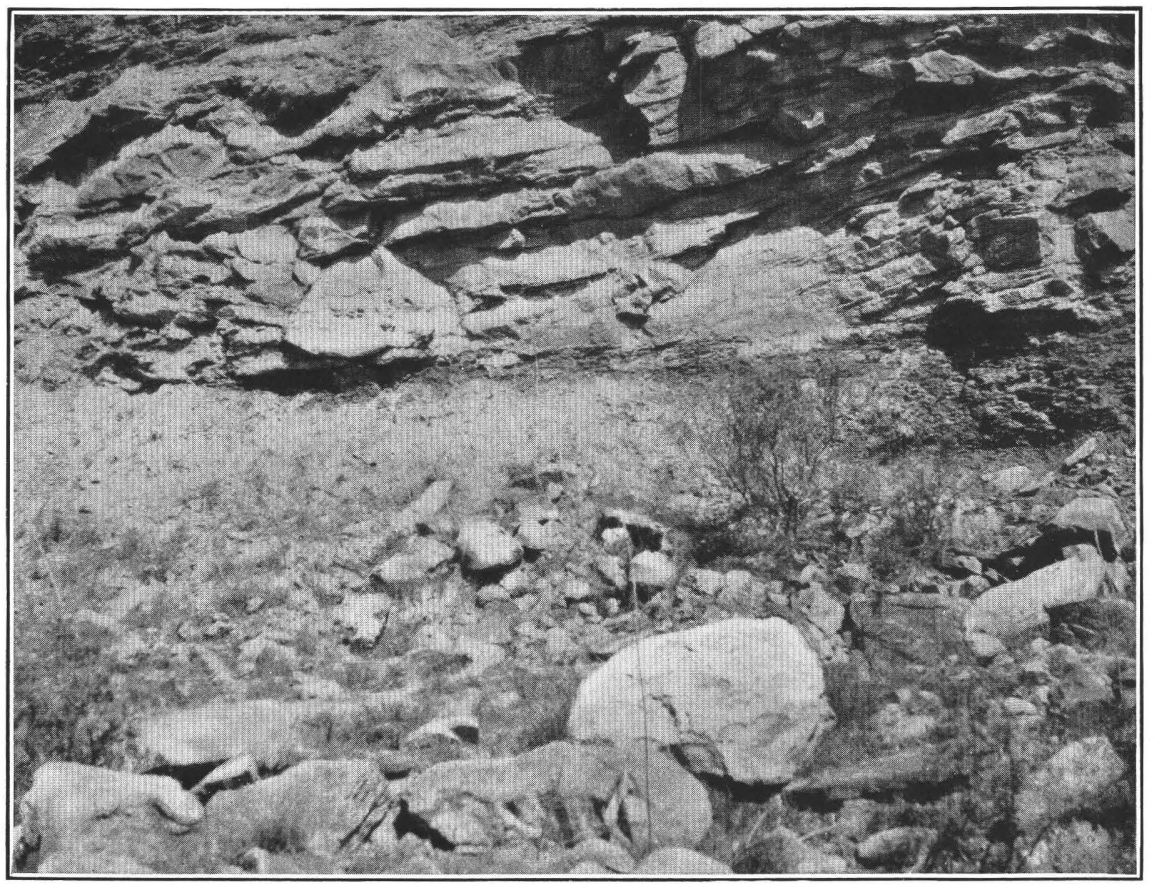

A. CONTACT BETWEEN THE MIDWAY FORMATION AND OVERLYING SANDSTONE OF MIDWAY OR WILCOX AGE ON THE RIO GRANDE IN MAVERICK COUNTY, TEX.

About $2 \frac{1}{2}$ miles above the Webb County line.

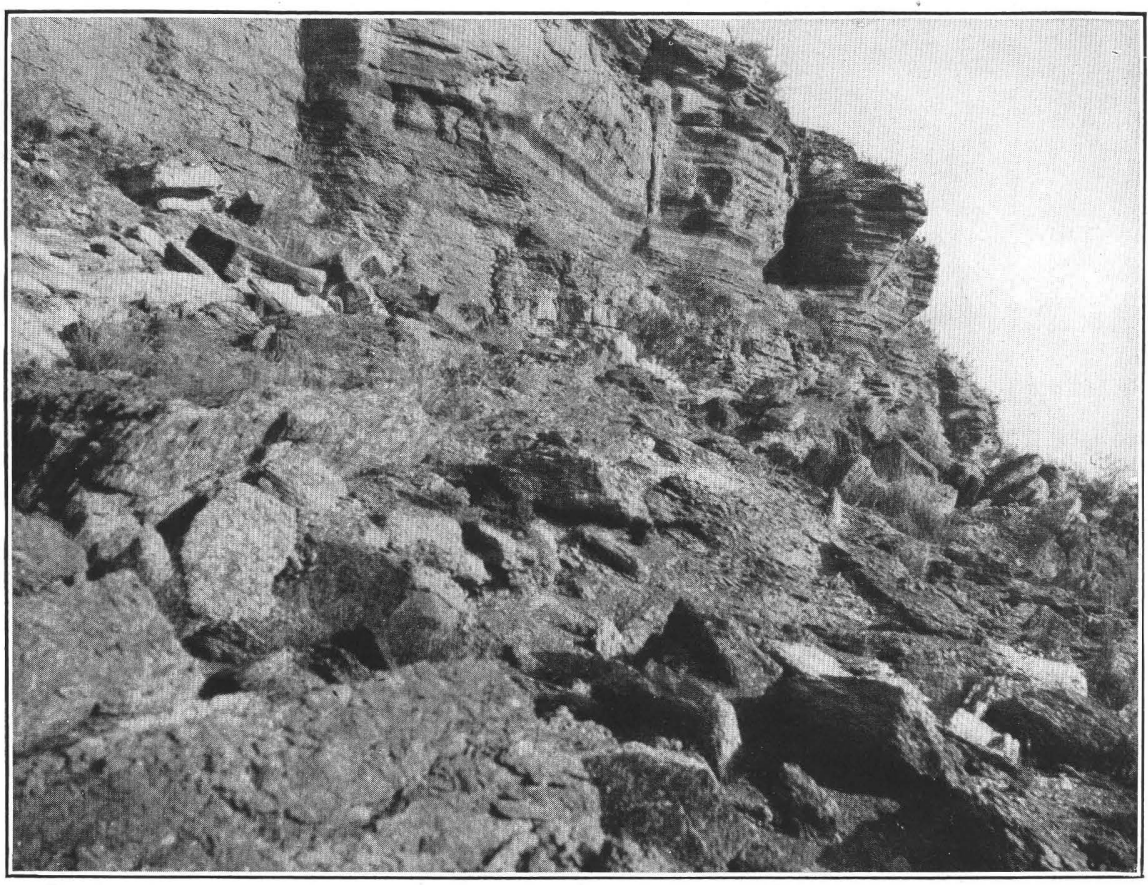

B. SANDSTONE OF MIDWAY OR WILCOX AGE IN A PROMINENT WESTWARDFACING BLUFF ON THE RIO GRANDE IN MAVERICK COUNTY, TEX. About 2 miles above the Webb County line. 
Pliocene or Pleistocene (Uvalde formation):

Feet.

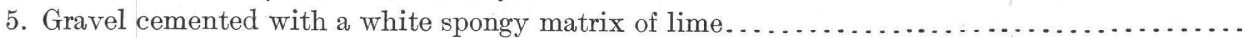

Unconformity.

Eocene (Midway formation):

4. Gray fossiliferous limestone in layers 1 to $2 \frac{1}{2}$ feet thick, interbedded with greenish-gray sand in layers 1 to 2 feet thick. The immediate base of the limestone is sandy and in places strongly glauconitic and contains balls and fragments of the underlying Cretaceous clay, present as a mechanical mixture. The limestone contains the following Eocene fossils (field No. 301), identified by T. W. Vaughan: Leda sp., Cucullæa macrodonta Whitfield, Cytherea ripleyana Gabb, Venericardia smithii Aldrich, and Venericardia perantiqua Conrad (U. S. G. S. collection 6575). A costate Anomia (field No. 302), probably derived from the underlying Cretaceous, is present as a mechanical mixture in the immediate base of the limestone.....

Unconformity; contact sharp and undulates slightly.

Upper Cretaceous (Escondido formation):

3. Greenish-gray shaly clay with crystals of gypsum. Contains a few interbedded lenses of fine greenish-gray sandstone. Grades downward into next layer......................

2. Greenish-gray glauconitic sand, partly indurated to nodular layers. Contains numerous Upper Cretaceous fossils, including Ostrea cortex Conrad, Cardium sp., numerous poorly preserved gastropods, and Sphenodiscus pleurisepta Conrad (field No. 303) ..............

1. Concealed to water's edge. . . . . . . . . . .

According to Mr. Vaughan, the fossils in layer No. 4 indicate the Midway age of the stratum.

The next place examined on the river was at a point about 1 mile below White Bluff and a quarter to half a mile below the Blesse ranch house, which is on the Mexican side. (See map, Pl. XV, and profile section, fig. 19.) Here the basal Eocene limestone, which is so prominently exposed near the top of White Bluff, dips below water level in the river bed. The rock is well exposed on the Texas side of the channel and extends for a considerable distance out into the river, which has cut a relatively narrow channel through the rock parallel to and near the south bank.

The writer was not able positively to identify the "falls of the Rio Grande" described by Dumble and others, but at this point a rise of the river a few feet above the ordinary low-water stage would result in more conspicuous rapids at the outcrop of this Eocene limestone than would be produced by other ledges of Cretaceous and Eocene rock which appear at many places in the bed of the river at low water, both above and below this point. It therefore seems likely that this is the so-called falls.

The base of the limestone is not exposed, but the thickness was estimated to be 10 or 15 feet. The inference is probably justified that here, as at White Bluff, the Cretaceous-Eocene contact lies immediately below the limestone, and the contact would therefore cross the river directly above the outcrop of the rock in the river bed. The limestone contains Venericardia sp. and other Eocene forms. The surface of the rock in the river bed has been strongly potholed and presents a rough, jagged appearance. (See Pl. XIV, B.)

A nearly continuous series of exposures appears along the left bank of the river from this point downstream to the prominent westward-facing bluff indicated on the map, a distance of about 2 miles. The beds overlying the limestone (division $d$ of profile section, fig. 19) dip downstream at the rate of at least 100 feet to the mile. In dark greenish-gray glauconitic sand, estimated to be 30 or 40 feet above the base of this division, a few black casts of gastropods and Venericardia sp. were collected (U. S. G. S. collection 6576; field No. 304), and about 35 feet.below the top of the division black casts of Venericardia sp. (U.S. G. S. collection 6577; field No. 305) were obtained. The beds of this division are of purely marine origin, as shown by the fossils and the glaueonite.

The marine division is overlain unconformably (see Pl. XVII, $A$ ) by irregularly bedded sandstones (division $e$, fig. 19), which form the major part of the prominent westward-facing bluff at the downstream end of the section. (See Pl. XVII, B.) This bluff rises 100 or 110 feet above water level (aneroid reading), but only the upper 60 or 70 feet is well exposed. Inter- 
bedded with the coarse sandstones in this section is a band of gypsiferous shale 10 to 15 feet thick, the top of which is about 20 feet below the top of the sandstone. The gypsum occurs in seams and separate crystals. The relation of these irregularly bedded sandstones to the typical Carrizo sandstone of Owen ${ }^{1}$ has not been determined, but they probably occupy a lower stratigraphic position, being equivalent in age either to a portion of the typical Midway group of Alabama or to the lower part of the overlying Wilcox group. The highest part of the bluff is capped by 3 or 4 feet of surficial gravel of the Uvalde formation.

Mr. Vaughan has informed the writer that the fossils enumerated in United States Geological Survey Bulletin 164, page 38, were found in beds below the typical Carrizo sandstone of Owen, and they may have come from the stra,ta represented by division $d$ of the profile section (fig. 19). According to Mr. Vaughan, the fossils indicate the Midway age of the containing beds. No fossils were found in division $e$ of the section, and therefore no additional evidence regarding its age can be presented.

The next exposure examined on the Rio Grande was a prominent westward-facing bluff 4 miles nearly due west or perhaps a little south of west of the Jacal ranch house and about 9 miles above the Maverick-Webb county line. The section is as follows:

Section at westward-facing bluff on Rio Grande about 9 miles. above the Maverick-Webb county line.

[Station 1 on the map, Pl. XV.]

Pliocene or Pleistocene (Uvalde formation):

6. Gravel

Unconformity.

Eocene (Midway formation):

5. Greenish sandy clay, with indurated layers a few feet apart, weathered and poorly exposed. 20

4. Hard gray limestone in layers 1 to 2 feet thick, with interbedded thinnerc layers of greenish fine, slightly indurated sand. The limestone is replete with Venericardia sp., Cucullæa sp., and other Eocene fossils (field No. 306a). A costate Anomia derived mechanically from the underlying Cretaceous strata occurs in the base of the limestone............

Exact contact not clearly exposed.

Upper Cretaceous (Escondido formation):

3. Greenish-gray shaly gypsiferous clay, with subordinate interbedded thin layers and some thicker layers of fine hard gray sandstone weathering greenish gray ............... 35

2. Greenish-gray massive marine sand, slightly indurated, some layers more indurated than others, and forming slightly projecting ledges. Fossils are numerous and the following were recognized: Breviarca sp., Ostrea cortex Conrad, Anomia sp. (with costæ), Mactra sp.?

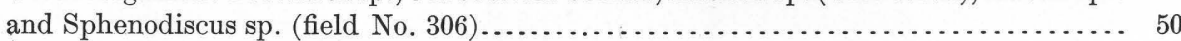

1. Concealed by talus and Recent alluvium............................ 35

The Cretaceous-Eocene contact is here about 120 feet above the water level of the river. The description given applies particularly to the upper end of the bluff, where a good exposure is afforded by the northwestward-facing side of a short gully. Good exposures of the fossiliferous beds of the Escondido formation (layer 2 of the section) extend southward for half a mile or more along the bluff.

A wire fence extends from the Jacal ranch house in a direct line west of south to White Bluff (see Pl. XV), and about 3 miles from the ranch house crosses a low peak, the top of which is nearly as high as the general level of the upland in the vicinity of the ranch house (200 feet or more above the river). The sandstone of Midway or Wilcox age is fairly well exposed in the upper 40 feet of this peak and consists of rather soft medium to coarse gray shaly sandstone with several more massive layers forming ledges. A few indistinct impressions of small pelecypods were noted.

Near the same fence, on the crest of a gravel-covered ridge, about $1 \frac{1}{2}$ miles from the Jacal ranch house, poorly preserved prints of Venericardia sp. were found in a partly exposed ledge of hard calcareous ferruginous sandstone.

A number of observations having an important bearing on the location of the CretaceousEocene contact in Maverick County were made along the road leading from the Jacal ranch 
house to Eagle Pass by way of the Biboro tank. (See map, Pl. XV.) About 6 miles from the ranch house (station $2, \mathrm{Pl}$. XV) a poor exposure of gray sandstone corresponding to the sandstone of Midway or Wilcox age shown in division $e$, figure 19, was observed in a small branch near the road, and associated with it were fragments of rock exhibiting cone in cone structure. Fragments of similar sandstone were noted along the same road for the next 3 miles toward Eagle Pass. From about the tenth to the eleventh mile from the ranch house the road where it cuts through the surficial loams and gravels of the Uvalde formation reveals greenish to yellowish clays, locally ferruginous and containing concretions of iron carbonate in different stages of oxidation. In ferruginous material, about 11 miles from the ranch house (station 3, Pl. XV), prints of Venericardia sp. (U. S. G. S. collection 6578; field No. 307), identified by C. W. Cooke, were obtained.

The next important exposure studied was at the crossing of Biboro Creek just below Biboro tank (station 4, Pl. V), which is estimated to be about 18 miles by the wagon road from Eagle Pass. The bed of the creek at the road crossing is about 20 feet below the general level of the surrounding upland. Ledges of hard gray fossiliferous limestone and greenish-gray calcareous sandstone crop out below the dam of the tank. From the limestone fossils were collected and identified by T. W. Vaughan and C. W. Cooke as follows: Cucullæa macrodonta Whitfield, Lucina sp., Cytherea ripleyana Gabb, Venericardia perantiqua Conrad var. smithii Aldrich?, and Enclimatoceras sp. nov. (U. S. G. S. collection 6583; field No. 308).

The rock corresponds exactly in its lithologic and faunal character to the basal Eocene limestone exposed along the Rio Grande south and west of the Jacal ranch house (division $c$ of the profile section, fig. 19). The exact base of the limestone was not discovered. According to Messrs. Vaughan and Cooke the fossils indicate the Midway age of the containing bed.

Within less than half a mile of Biboro Creek in the direction of Eagle Pass (station 5, Pl. XV), fragments of fine greenish-gray sandstone belonging to the Escondido formation of the Upper Cretaceous were noted along the road. In descending the northwestward-facing slope of Cuevas Creek, about $1 \frac{1}{2}$ miles from Biboro tank, the roadbed reveals greenish-gray, more or less argillaceous, slightly indurated sand, in which some layers are more indurated than others and form ledges. The rock is fossiliferous and the following poorly preserved forms were collected: Breviarca sp., Ostrea cortex Conrad, Anomia sp., Cardium sp., Mactra sp.?, and Sphenodiscus pleurisepta Conrad (field No. 309). These are characteristic species of the Escondido formation. Similar beds are exposed in the bed of Cuevas Creek at the road crossing, and here a few well-preserved specimens of Sphenodiscus sp. were collected (field No. 310).

Although the base of the Eocene limestone was not seen in the vicinity of Biboro tank, the appearance of Cretaceous strata within less than half a mile to the northwest shows that the contact between the two systems lies a short distance west of the tank, and it must intersect Biboro Creek below the road crossing, possibly within a few rods. Between Cuevas Creek and Eagle Pass the only strata exposed, except the surficial gravels and loams of the Uvalde formation, belong to the Upper Cretaceous.

The next place north of Biboro tank at which data bearing on the geographic position of the contact were obtained was in the valley of Picoso Creek between the Chimeneas ranch house and the Joe Williams ranch house. (See map, Pl. XV.) Aside from the surficial loams and gravels of the Uvalde formation, the only rocks observed along the road from Eagle Pass to the Chimeneas ranch house belonged to the Upper Cretaceous. A few hundred yards east of this ranch house (station $6, \mathrm{Pl} . \mathrm{XV}$ ) a layer of hard nodular fossiliferous limestone crops out in the bed of a small creek and along the gentle bordering slopes and yielded specimens of Exogyra costata Say and Cardium spillmani Conrad? (field No. 314). The rock therefore belongs to the Escondido formation of the Upper Cretaceous. Similar rock was observed in the bed of the same creek about a mile east of the ranch house, and also in the bed of Picoso Creek at a road crossing about $2 \frac{1}{2}$ miles northeast of the ranch house (station $7, \mathrm{Pl}$. XV), where poorly preserved specimens of Exogyra costata Say were noted. 
From the crossing of Picoso Creek along the road northward for 2 or $2 \frac{1}{2}$ miles and then eastward toward the Joe Williams ranch house (see Pl. XV), poor exposures of sandstone of the Escondido formation were noted here and there to a point within about 1 mile west of the ranch house, beyond which the road was heavy with sand. In the immediate vicinity of the ranch house several small exposures of gray, rather coarse sandstone having the characteristics of the sandstone unconformably overlying the marine Midway on the Rio Grande (division $e$, fig. 19), were observed. From the Joe Williams ranch house southward to Picoso Creek, a distance of 2 or $2 \frac{1}{2}$ miles, several small outcrops of this sandstone appear along the road. A fairly good exposure of the same formation was found in the bed of a small branch, perhaps 2 miles south of the ranch house (station $8, \mathrm{Pl}$. XV). Here the rock consists of soft medium to coarse grained irregularly bedded massive to thin-bedded sandstone, containing numerous grains, films, and small balls of white clay, and on weathering the surface is mottled with red.

These observations indicate that the Cretaceous-Eocene contact lies about 1 mile west of the Joe Williams ranch house. The intersection of the contact with Picoso Creek is probably a little west of south of the ranch house.

A few small outcrops of the gray sandstone corresponding to division $e$ of figure 19 appear along the road leading west of north from the Joe Williams ranch house to the Burke ranch house, a distance of 3 or 4 miles. The same sandstones were noted in small, inconspicuous exposures at numerous places along an abandoned roadway which leads in a general northerly direction from Burke's ranch house across Chacon Creek to Black's ranch house, an air-line distance of 5 or 6 miles. They were seen also about 1 mile northwest of Black's ranch house (station 9, Pl. XV) in several small exposures in and near the road leading toward the Salado ranch. No significant exposures were found beyond these outcrops, but specimens of Sphenodiscus sp. were observed loose in the bed of a small creek about $1 \frac{1}{2}$ miles a little north of east of the Salado ranch house.

At an abandoned tank on Salado Creek just south of the Salado ranch house along the Eagle Pass-Uvalde road (station 10, Pl. XV) typical sandstones of the Escondido formation were examined. The rock is a gray hard, more or less calcareous sandstone and contains fossils among which were recognized Breviarca sp., Ostrea cortex Conrad, Gyrodes sp., and two species of Sphenodiscus (field No. 315).

From the Salado ranch house along the road running 4 or $4 \frac{1}{2}$ miles in a southeasterly direction to Chiltipin tank, which is situated in a small valley draining eastward (station 11, Pl. XV) characteristic sandstones of the Escondido formation were observed in many small outcrops. Along the sides of the valley below the tank are large masses of hard gray sandstone, weathering brown, belonging to the Escondido formation. Some lenses are very fossiliferous, but the fossils are not easily separated from the matrix. The following forms were recognized: Breviarca sp., Ostrea cortex Conrad, Anomia sp., unidentified gastropods, and Sphenodiscus sp.

The data above presented show that the outcrop of the Cretaceous-Eocene contact probably lies within 1 or 2 miles west of the Joe Williams ranch house, and that north of this place the possible outcrop is limited to an area a few miles wide which lies west of the Burke and Black ranch houses and east of Chiltipin tank and the Salado ranch house.

As no marine invertebrate-bearing beds corresponding to the strata of the Midway formation (Eocene), which outcrop along the Rio Grande, were seen in this area, it appears that the gray sandstones unconformably overlying the marine Midway deposits on the Rio Grande have here transgressed westward, concealing the marine Midway strata and resting upon the Escondido formation (Upper Cretaceous).

\section{ZAVALLA AND UVALDE COUNTIES}

Vaughan ${ }^{1}$ has approximately determined the Cretaceous-Eocene contact in the northwestern part of Zavalla County and the southern part of Uvalde County as far east as Frio River and exactly at one locality on Frio River. The only additional data resulting from the

1 Vaughan, T. W., Reconnaissance in the Rio Grande coal fields of Texas: U. S. Geol. Survey Bull. 164, pp. 53, 54, Pl. I, 1900; U. S. Geol. Survey Geol. Atlas, Uvalde folio (No. 64), pp. 2, 3, 1900; idem, Brackett folio (in preparation). 
writer's field studies west of Frio River relate to certain outcrops west of south of the old Fenley ranch house. About $4 \frac{1}{2}$ miles south of the Eagle Pass and Uvalde road, near the ZavallaMaverick county line, about a quarter of a mile south of a new ranch house (station 12, Pl. $\mathrm{XV}$ ), is a small exposure of hard gray quartzite-like rock showing faint stratification lines and having the characteristics of the gray Eocene sandstones on the Rio Grande shown in figure 19, e. About 14 miles north of this point, near the road leading northward to the Uvalde and Eagle Pass road (station 13), are several small outcrops of rock typical of the Escondido formation of the Upper Cretaceous ("Pulliam" formation of Vaughan), consisting of hard greenish-gray fine-grained calcareous sandstone. These data limit the possible outcrop of the contact to a belt less than 2 miles wide.

The writer has examined some of the fossils which were obtained by Vaughan from his Myrick formation just above the Cretaceous-Eocene contact on Frio River in the southeastern part of Uvalde County, 2 miles below Engelmann's ranch, and which he states indicate the Midway age of the strata in which they were found. The matrix is a weathered glauconitic phase of the basal Eocene (Midway) limestone, division $c$ of the profile section given in figure 19. The Myrick formation, which Vaughan estimates to be 800 feet thick, must therefore include strata belonging to the Midway formation and to overlying undifferentiated Eocene formations. The fossils collected and identified by Vaughan from the basal stratum of the Eocene at this locality are the following (U. S. G. S. collection 3181):

$\begin{array}{lll}\text { Cucullæa saffordi (Gabb). } & \text { Venericardia sp. } & \text { Turritella humerosa Conrad. } \\ \text { Ostrea crenulimarginata Gabb? } & \text { Lucina sp. } & \text { Turritella mortoni Conrad. } \\ \text { Ostrea pulaskensis Harris. } & \text { Cytherea sp. } & \text { Levifusus trabeatus (Conrad) var.? } \\ \text { Venericardia perantiqua Conrad. } & \text { Natica sp. } & \text { Nautilus sp. nov. }\end{array}$

In the eastern part of Uvalde County the Cretaceous-Eocene contact was determined by the writer to be in the northwestward-facing slope of Elm Creek near the Schuddemagen ranch house, which is just north of the junction of the creek with Sabinal River. (See map, fig. 20.) With the exception of a prominent limestone ledge (layer 4 of the section below; see also Pl. XVIII, A) the strata forming the hill are not well exposed, but by a close inspection of small outcrops along the slope the following section was determined:

Section in northwestward-facing slope of Elm Creek near the Schuddemagen ranch house, 11 miles south of Sabinal, Tex.

[Station 14, fig. 20.]

Pliocene or Pleistocene (Uvalde formation): Feet.

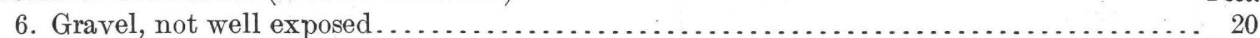

Eocene (Midway formation):

5. Fine greenish-gray, slightly calcareous sand with numerous interbedded thin layers of sandstone, the whole poorly exposed. At one place the basal 2 or 3 feet is replete with Ostrea sp. (apparently new) (U. S. G. S. collection 6278; field No. $247 d$ ) . . . . . . . . . 50

4. Massive sandy limestone with poorly preserved fossils, prominently exposed along the hill slope. Messrs. Vaughan and Cooke have identified the following species from this limestone: Glycymeris sp., Ostrea sp., Venericardia perantiqua Conrad var. smithii Aldrich, Cytherea ripleyana Gabb, Natica sp., Turritella mortoni Conrad, Turritella sp., Calyptraphorus velatus Conrad var., Pseudoliva cf. P. unilineata Aldrich, Phos? sp., Pleurotoma sp. (U. S. G. S. collection 6279; field No. 247c) ..................... 10

Exact Cretaceous-Eocene contact was not observed, but it probably lies at the top of layer 3. Upper Cretaceous (Escondido formation = "Pulliam" formation of Vaughan):

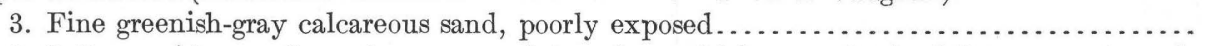

2. Soft greenish-gray fine calcareous sandstone from which were obtained Ostrea sp., Anomia sp., and Sphenodiscus sp. (field No. 247a); poorly exposed .................... 3

1. Greenish-gray fine calcareous sand, poorly exposed........................ 18

Layer 4 of the section (PI. XVIII, $A$ ) corresponds in lithologic character to the basal Eocene limestone exposed along the Rio Grande in the southern part of Maverick County (division $c$ of the profile section, fig. 19, p. 172), and Messrs. Vaughan and Cooke state that the fossils indicate the Midway age of the stratum.

Small outcrops of Cretaceous rock were noted at several places between the Schuddemagen ranch house and Sabinal. 
MEDINA COUNTY.

The position of the Cretaceous-Eocene contact was determined approximately along the road leading from D'Hanis, Medina County, Tex., a little east of south to Yancey. At a point $7 \frac{1}{2}$ miles from D'Hanis, near the crest of a northeastward-facing slope (station 15, fig. 20), about 15 feet of hard white limestone is moderately well exposed. Among fossils collected from this limestone C. W. Cooke identified Cucullxa macrodonta Whitfield?, Ostrea crenulimarginata Gabb, Venericardia perantiqua Conrad, Lucina sp., and unidentified gastropod fragments (U. S. G. S. collection 6584; field No. 340). In its lithologic character the rock corresponds to the basal Eocene limestone in Maverick County (division $c$ of the profile section, fig. 19), and according to Mr. Cooke the fossils indicate the Midway age of the bed.

The exact base of the limestone was not observed, but along the road about a quarter of a mile north of the outcrop and not more than 10 or 15 feet lower than the lowest exposed

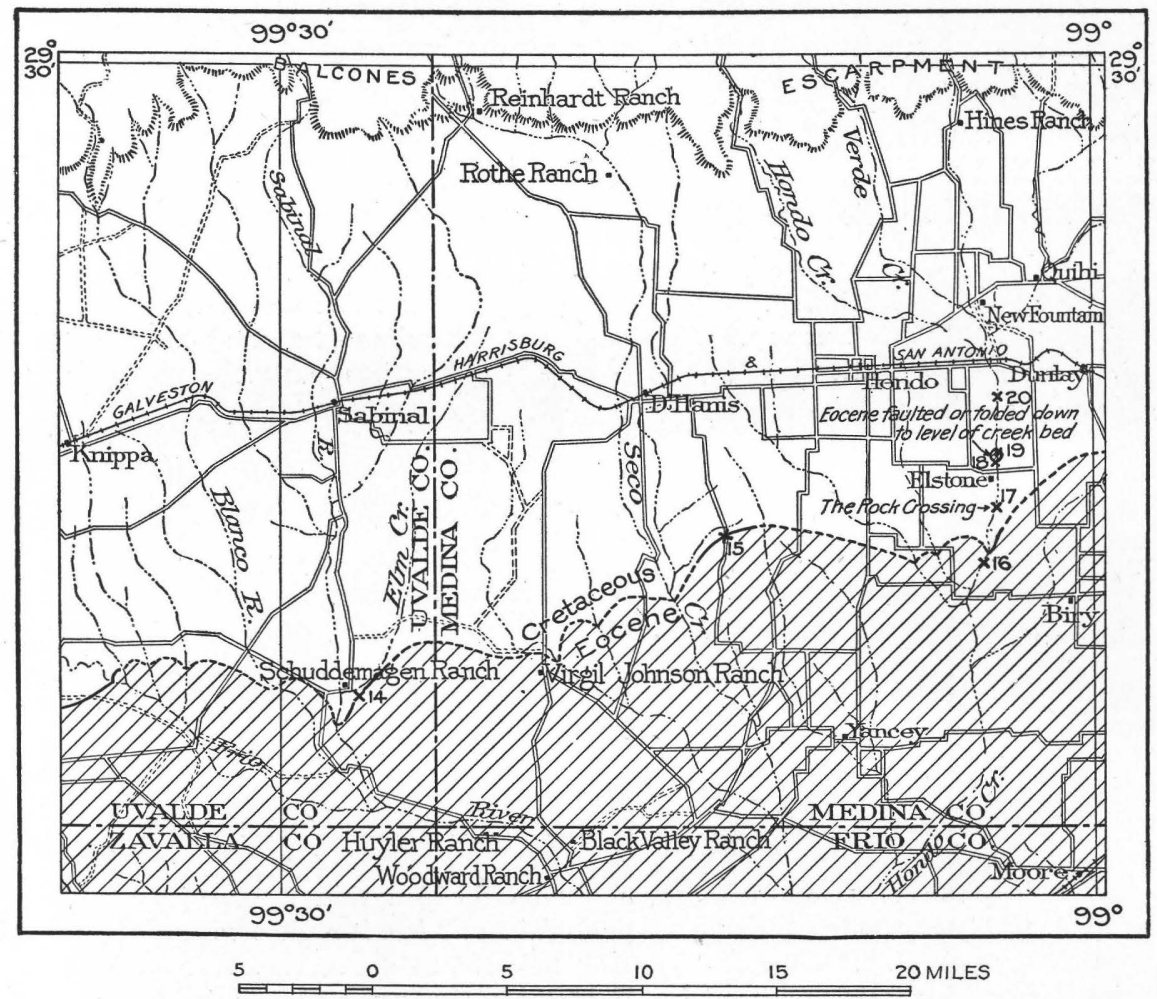

FiguRE 20.-Sketch map showing outcrop of Cretaceous-Eocene contact in portions of Uvalde and Medina counties, Tex. The full line indicates places where the contact has been determined with a fair degree of accuracy; the dashed line indicates the approximate or inferred position of the outcrop. portion of the limestone the Cretaceous fossils Ostrea cortex Conrad and Anomia sp. were found in an impure yellow limestone. The contact is therefore determined within a horizontal distance of less than a quarter of a mile. No direct aneroid reading was made, but the base of the limestone of Midway age is estimated to be at least 160 feet higher than the bed of Seco Creek west of this locality.

Between the locality just described and D'Hanis, aside from surficial loams and gravels, only Cretaceous strata were observed.

On Hondo Creek $3 \frac{1}{2}$ miles south of Elstone, half a mile south of the Lon Moore crossing (station 16, fig. 20), masses of gray to brown, strongly cross-bedded medium to fine, slightly calcareous sandstone with interbedded thin layers showing cone in cone structure are prominently exposed in the bed of the creek and along the left bank for several hundred yards. (See Pl. XVIII, B.) Although no fossils were found, this rock has the lithologic aspect of some phases of the sandstone (division $e$, fig. 19) unconformably overlying the marine Midway on the Rio Grande. Similar sandstones appear in the creek bed for the next mile below this point, and other outcrops of sands, sandstones, and clays, probably Eocene, were observed still farther down the creek within $6 \frac{1}{2}$ miles below Elstone.

At a locality on Hondo Creek known as Rock Crossing (station 17, fig. 20), which is about $1 \frac{1}{4}$ miles below the crossing of. the road leading due east from Elstone and one-half to threequarters of a mile above the Blue Water Hole (on the Elstone-Biry road crossing), fossiliferous strata of Cretaceous age are well exposed. (See Pl. XIX, A.) The section is as follows: 


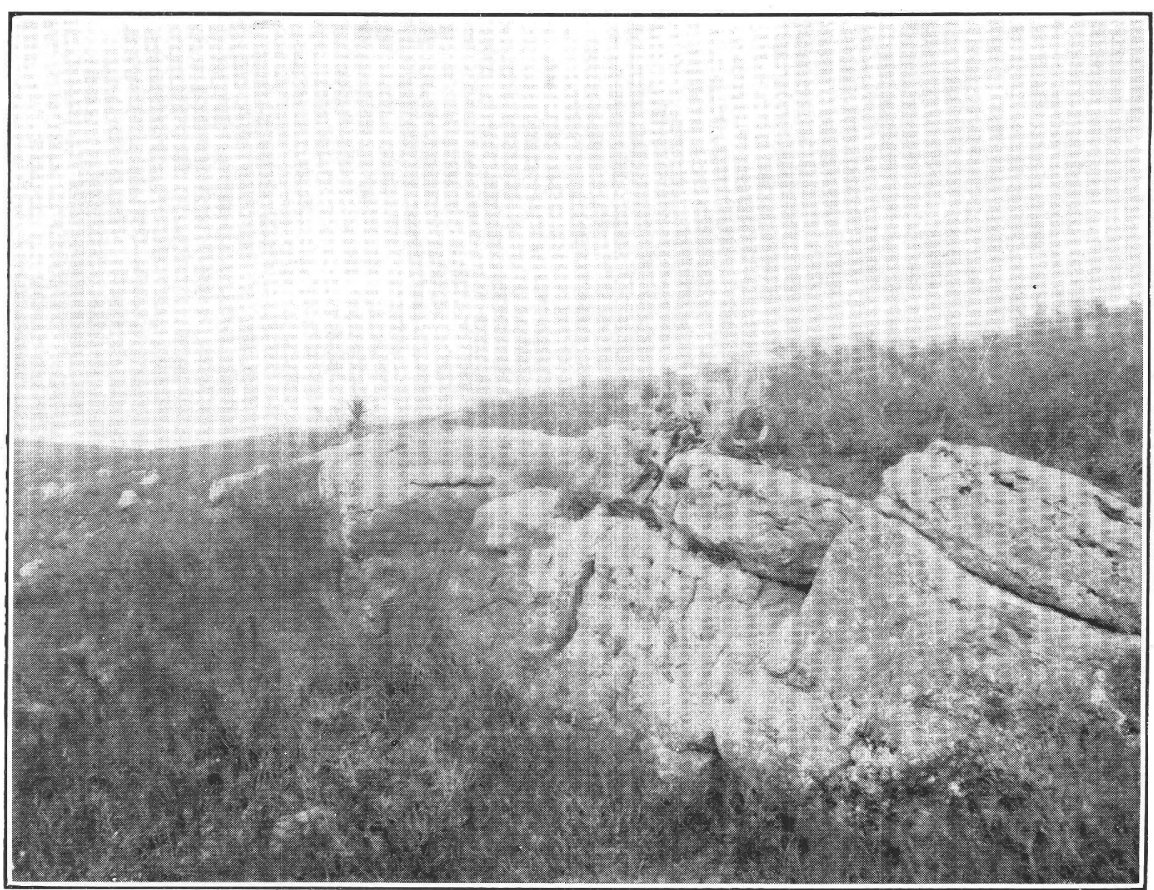

A. BASAL LIMESTONE OF MIDWAY FORMATION ON SOUTHEAST SIDE OF ELM CREEK 11 MILES SOUTH OF SABINAL, TEX.

Near Schuddemagen ranch house.

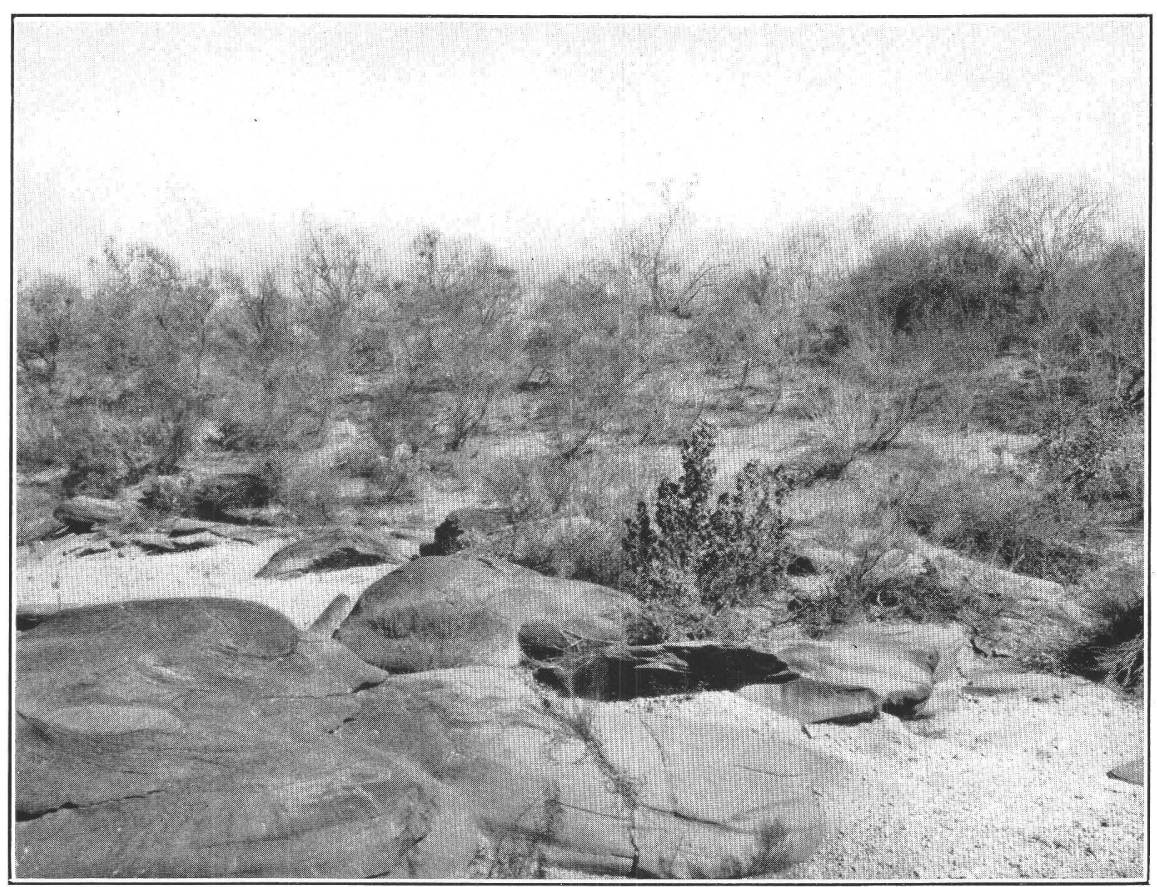

B. EOCENE SANDSTONE IN BED OF HONDO CREEK $3 \frac{1}{2}$ MILES SOUTH
OF ELSTONE, TEX. 


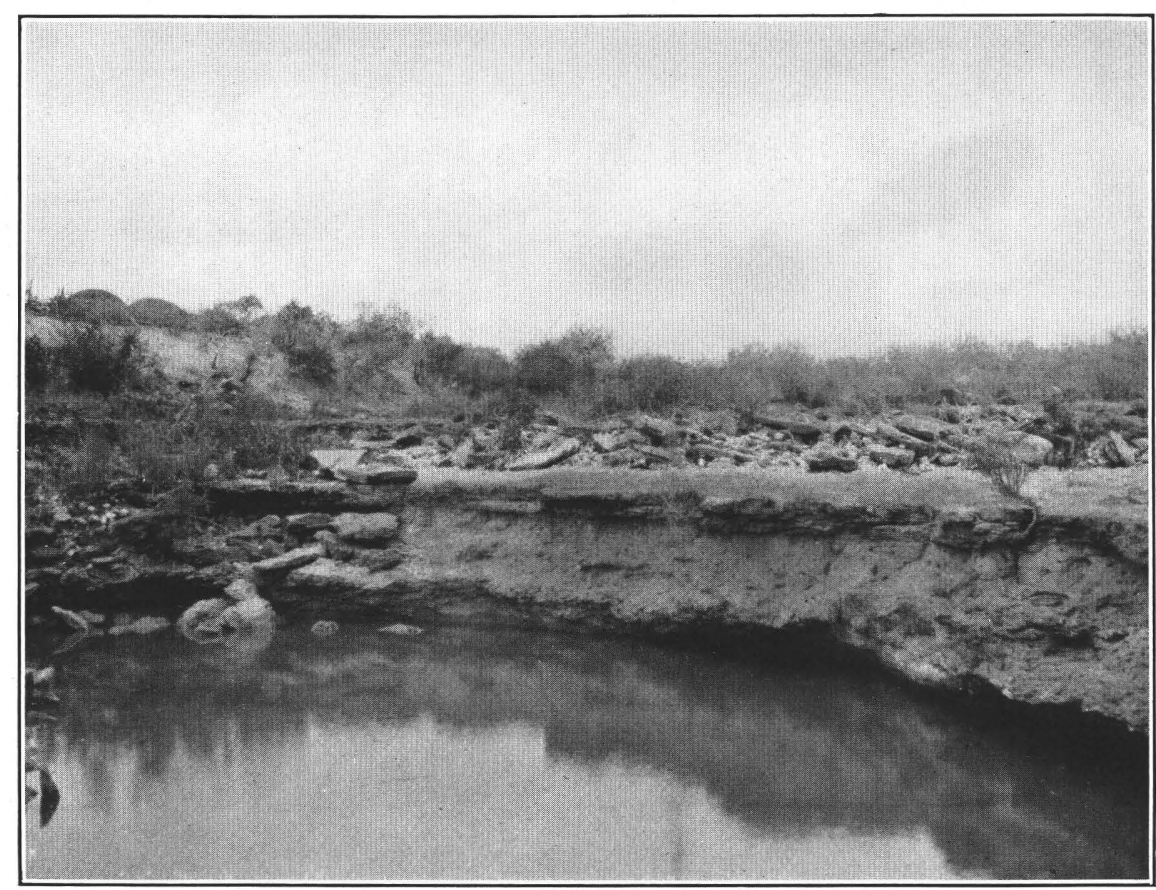

A. ESCONDIDO FORMATION IN BED OF HONDO CREEK AT ROCK CROSSING, MEDINA COUNTY, TEX.

About $1 \frac{1}{4}$ miles below the crossing of the road leading east from Elstone. Sphenodiscus (several varieties) occurs abundantly in these strata.

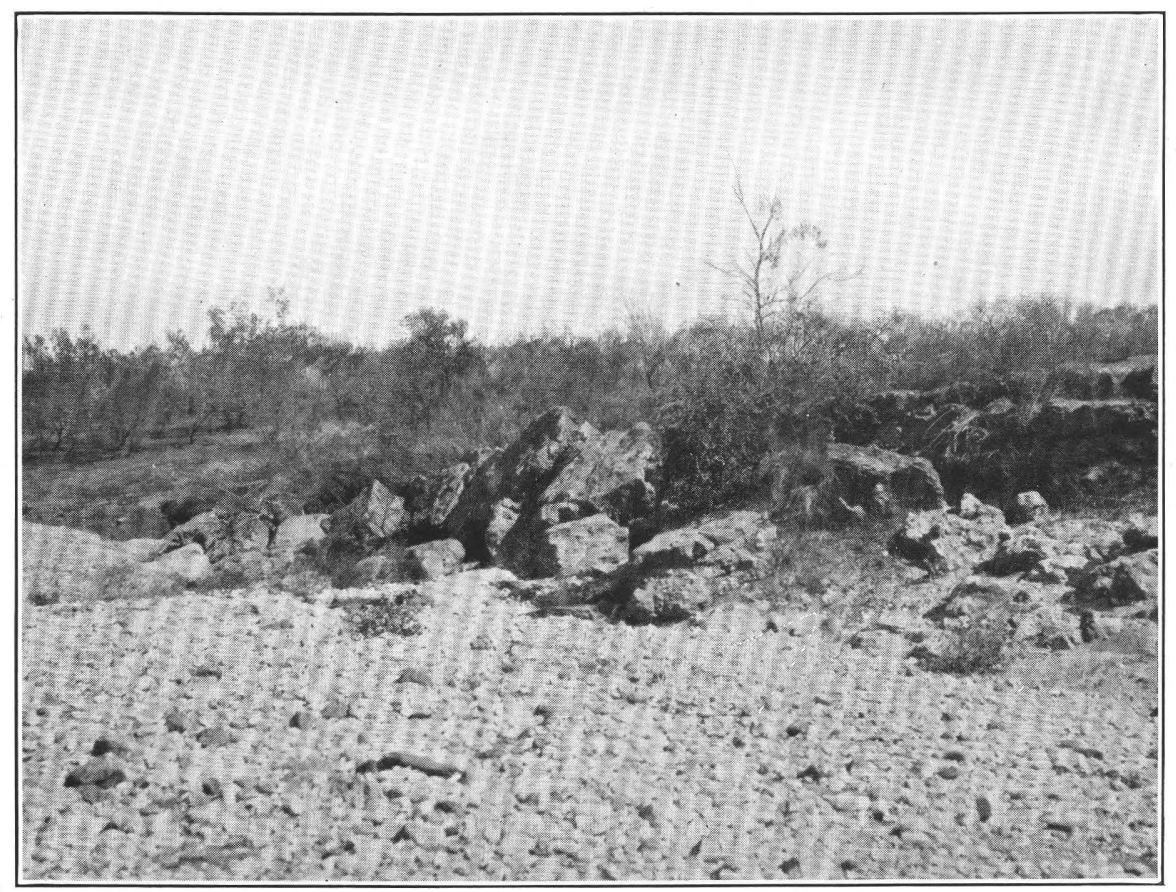

B. BASAL LIMESTONE OF MIDWAY FORMATION ON LEFT BANK OF HONDO CREEK IN MEDINA COUNTY, TEX.

About a quarter of a mile above the crossing of the road leading east from Elstone. 
Section at Rock Crossing on Hondo Creek, Medina County, Tex.

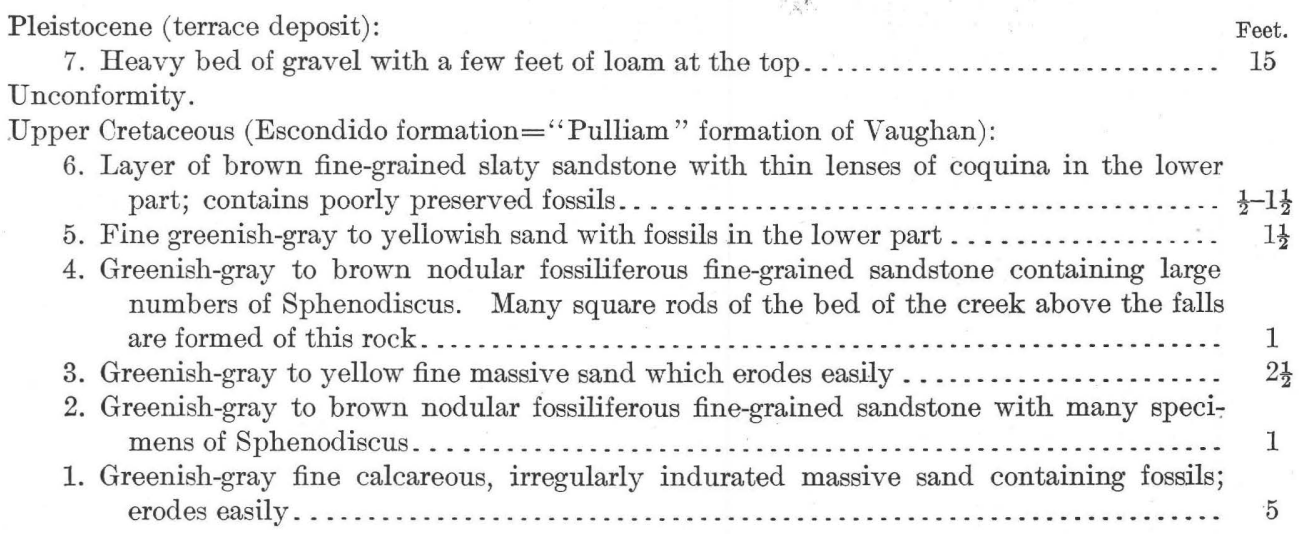

Layers 1 and 2 form the head of a shallow gorge which is a waterfall when there is running water in the creek. (See Pl. XIX, A.) Layer 4 also forms a small waterfall a few rods farther up the creek.

The following fossils (field No. 221) were obtained from layers 1 to 5 of the section:

$\begin{array}{llc}\text { Ostrea cortex Conrad. } & \text { Lunatia? } & \text { Sphenodiscus pleurisepta Conrad. } \\ \text { Ostrea sp. } & \text { Turritella sp. } & \text { Sphenodiscus (several varieties or } \\ \text { Anomia sp. } & \text { Undetermined gastropods. } & \text { species). } \\ \text { Cardium sp. } & \text { Nautilus sp. } & \end{array}$

About a quarter of a mile below Rock Crossing 12 feet of strata lithologically corresponding to layers 1 to 5 of the section appear in a vertical bluff along the left bank of the creek. Several fine large specimens of Sphenodiscus were obtained here (field No. 223).

According to these observations, the Cretaceous-Eocene contact must intersect the creek between stations 16 and 17 , which are 2 or $2 \frac{1}{2}$ miles apart. It is probably nearer station 16 than station 17.

About a quarter of a mile above the crossing of the road leading due east from Elstone (station 18, fig. 20) the left bank of Hondo Creek exposes 12 or 15 feet of hard, sandy, slightly glauconitic limestone, somewhat like coquina in appearance. (See Pl. XIX, B.) The rock is poorly fossiliferous, but Ostrea sp. and Turritella mortoni Conrad? (field No. 219) were recognized. About three-eighths of a mile below this point, one-eighth of a mile below the crossing of the road leading due east from Elstone, a loose bowlder found in the bed of the creek and obviously derived from the limestone yielded a few poorly preserved fossils, among which Messrs. Cooke and Vaughan have recognized the following species (U. S. G. S. collection 6280; field No. 220):

Leda elongatoidea Aldrich var.? Harris.

Glycymeris sp.

Ostrea sp.

Modiola saffordi Gabb.

\author{
Venericardia sp. \\ Cytherea sp. \\ Corbula sp. \\ Turritella sp.
}

The rock is therefore of Eocene age. It has the general appearance of the basal limestone of the Midway formation noted $7 \frac{1}{2}$ miles southeast of D'Hanis and near the Schuddemagen ranch and is believed to correspond to the basal limestone of the Midway exposed on the Rio Grande in southern Maverick County (division $c$ of the profile section, fig. 19).

Half a mile above the locality just mentioned large masses of gray medium-grained crossbedded, slightly calcareous sandstone, weathering brown, appear along the left bank of the creek (station 19, fig. 20). They are slightly out of place, having fallen from their original position. These rocks are unlike the fine-grained sandstones of the underlying Escondido formation (Upper Cretaceous) and closely resemble some phases of the Eocene in this part of Texas. The sandstone and the limestone noted a quarter of a mile above the road crossing 
east of Elstone (p. 179), occurring $1 \frac{1}{2}$ to 2 miles above the Cretaceous strata exposed at Rock Crossing on Hondo Creek, indicate a fold or fault which brings the Eocene down to the level of the creek bed, farther upstream than it would be if the strata were regularly inclined.

About 3 miles upstream from the sandstone just described and $1 \frac{1}{2}$ or $1 \frac{3}{4}$ miles below the San Antonio and Hondo road crossing (station 20, fig. 20), Cretaceous sand was found exposed in the right bank of the creek as described in the following section:

Section in right bank of Hondo Creek $1 \frac{1}{2}$ or $1 \frac{3}{4}$ miles below the San Antonio-Hondo road bridge.

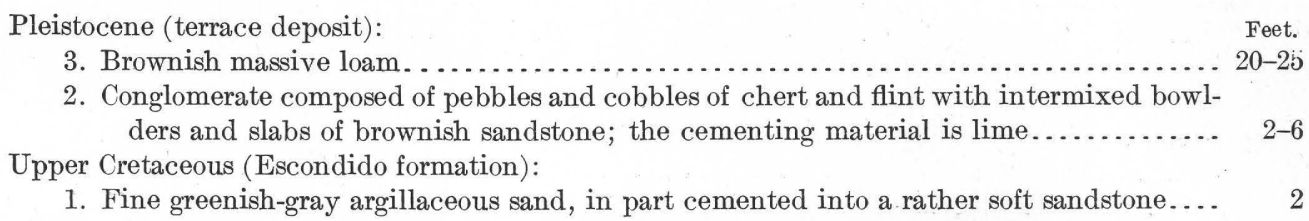

A few hundred yards above this exposure numerous large slabs of gray sandstone, weathering brown, appear in the bed of the creek, and though not seen in place they mark the outcrop of a ledge of sandstone of the Escondido formation. With the exception of Pleistocene terrace deposits, no strata younger than Cretaceous were observed along Hondo Creek between the locality last described and the Balcones escarpment.

\section{SUMMARY OF RESULTS IN SOUTHWESTERN TEXAS.}

The data set forth on the preceding pages show that along the Rio Grande in the southern part of Maverick County the following succession of formations exists:

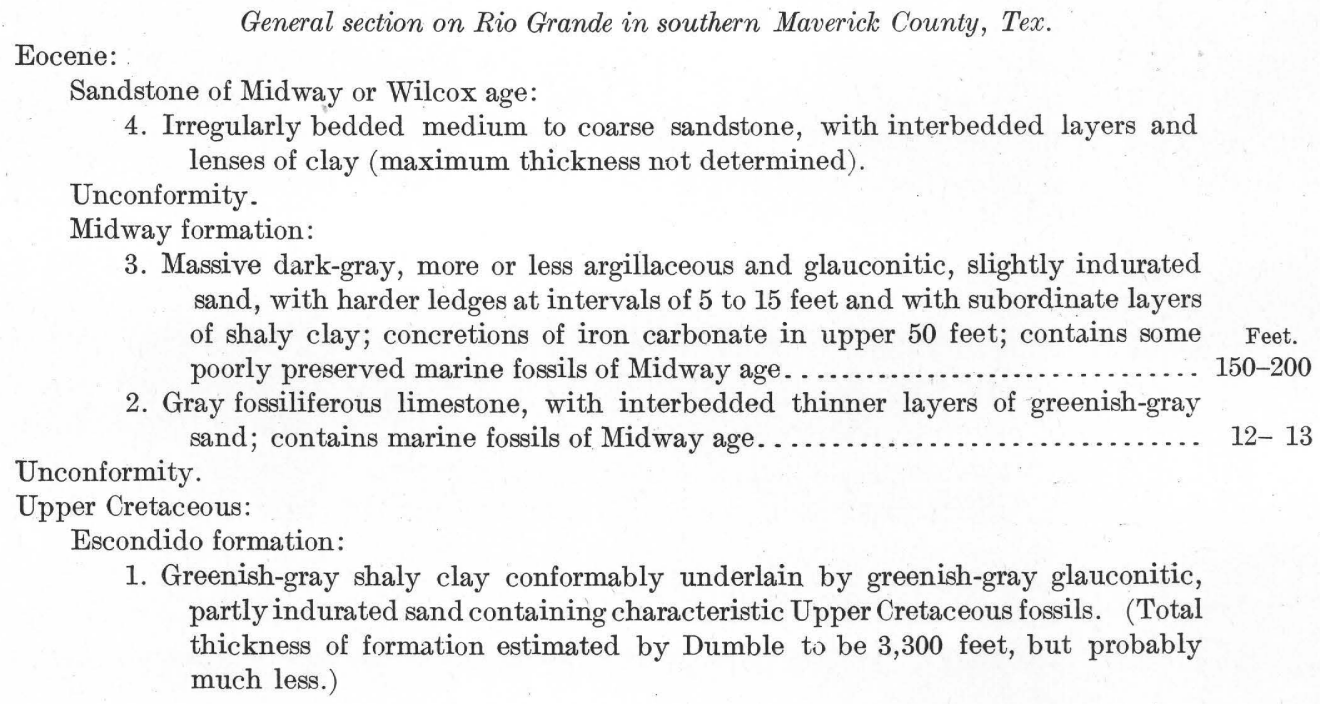
sand, with harder ledges at intervals of 5 to 15 feet and with subordinate layers of shaly clay; concretions of iron carbonate in upper 50 feet; contains some Feet. poorly preserved marine fossils of Midway age . ...................... 150-200

2. Gray fossiliferous limestone, with interbedded thinner layers of greenish-gray sand; contains marine fossils of Midway age..................... $12-13$

1. Greenish-gray shaly clay conformably underlain by greenish-gray glauconitic, partly indurated sand containing characteristic Upper Cretaceous fossils. (Total thickness of formation estimated by Dumble to be 3,300 feet, but probably much less.)

The basal limestone of the Midway formation has been traced eastward as far as Hondo Creek, Medina County, the underlying formation being the Escondido formation of the Upper Cretaceous. In an area including the northeastern part of Maverick County, the northwestern part of Zavalla County, and the southwestern part of Uvalde County the Midway appears to be completely overlapped by a northwestward transgression of younger sandstone of Midway or Wilcox age.

The lower part of the Escondido formation of southwestern Texas certainly corresponds to at least a part of the Exogyra costata zone of the eastern Gulf region. Exogyra costata Say has not been found in the upper part of the Escondido formation, and it may be that that part is somewhat younger than this zone. The fauna of the formation has not been critically studied, but the ammonite Sphenodiscus pleurisepta Conrad ranges throughout practically the whole thickness of the terrane, being most abundant near the top, where it is represented by several varieties. The fauna is therefore strictly Mesozoic in its aspects, and in a geologic sense the 
upper part of the Escondido is not very much younger than the Exogyra costata zone. These uppermost strata probably do not appreciably bridge the great hiatus between the Cretaceous and Eocene.

\section{LITERATURE.}

It is impracticable in this paper to give a complete bibliography of the literature relating to the Cretaceous-Eocene contact in the Atlantic and Gulf Coastal Plain. The papers enumerated below include only those in which may be found compilations of the available data relating to the contact in the areas treated. Nearly all the papers cited contain bibliographies and references to older literature and maps showing the outcrop of the contact.

GENERAL.

1891. White, C. A., Correlation papers-Cretaceous: U. S. Geol. Survey Bull. 82, 273 pp., geologic map.

1892. Clark, W. B., Correlation papers-Eocene: U. S. Geol. Survey Bull. 83, pp. 1-94, generalized geologic map.

1896. Harris, G. D., The Midway stage: Bull. Am. Paleontology, vol. 1, pp. 117-270.

1897. Clark, W. B., and others, Upper Cretaceous deposits of New Jersey, Delaware, and Maryland: Geol. Soc. America Bull., vol. 8, pp. 315-358, geologic map.

1898. Dall, W. H., A table of North American Tertiary horizons: U. S. Geol. Survey Eighteenth Ann. Rept., pt. 2 , pp. 332-335.

1912. Willis, Bailey, and others, Index to the stratigraphy of North America: U. S. Geol. Survey Prof. Paper 71, 894 pp., geologic map.

1914. Stephenson, L.W., The Cretaceous deposits of the eastern Gulf region: U. S. Geol. Survey Prof. Paper 81, pp. 9-40, geologic map.

NEW JERSEY

1897. Clark, W. B., and others, Upper Cretaceous deposits of New Jersey, Delaware, and Maryland: Geol. Soc. America Bull., vol. 8, pp. 315-358, geologic map.

MARYLAND.

1897. Clark, W. B., and others, Upper Cretaceous deposits of New Jersey, Delaware, and Maryland: Geol. Soc. America Bull., vol. 8, pp. 315-358, geologic map.

1901. Clark, W. B., and Martin, G. C., The Eocene deposits of Maryland: Maryland Geol. Survey, Eocene, 331 pp., geologic map.

VIRGINIA.

1912. Clark, W. B., Miller, B. L., and Berry, E. W., Physiography and geology of the Coastal Plain province of Virginia: Virginia Geol. Survey Bull. 4, pp. 1-222, geologic map.

NORTH CAROLINA.

1912. Clark, W. B., Miller, B. L., and Stephenson, L. W., The stratigraphy of the Coastal Plain of North Carolina: North Carolina Geol. and Econ. Survey, vol. 3, pp. 34-330, geologic map in pocket.

SOUTH CAROLINA.

1908. Sloan, Earle, Catalogue of the mineral localities of South Carolina: South Carolina Geol. Survey, 4th ser., Bull. 2, pp. 434-485, geologic map.

GEORGIA.

1911. Veatch, Otto, and Stephenson, L. W., Preliminary report on the geology of the Coastal Plain of Georgia: Georgia Geol. Survey Bull. 26, 466 pp., geologic map.

ALABAMA.

1887. Smith, E. A., and Johnson, L. C., Tertiary and Cretaceous strata of the Tuscaloosa, Tombigbee, and Alabama rivers: U. S. Geol. Survey Bull. 43, 189 pp.

1894. Smith, E. A., Johnson, L. C., and Langdon, D. W., jr., Geology of the Coastal Plain of Alabama: Alabama Geol. Survey, $759 \mathrm{pp}$.

1894. Smith, E. A., Johnson, L. C., and Langdon, D. W., jr., Geologic map of Alabama: Alabama Geol. Survey.

1914. Stephenson, L. W., The Cretaceous deposits of the eastern Gulf region: U. S. Geol. Survey Prof. Paper 81, pp. 9-40, geologic map. 
MISSISSIPPI.

1860. Hilgard, E. W. [State geologist], Geology and agriculture of the State of Mississippi, 391 pp., geologic map.

1906. Crider, A. F., Geology and mineral resources of Mississippi: U. S. Geol. Survey Bull. 283, 99 pp., geologic map. 1914. Stephenson, L. W., The Cretaceous deposits of the eastern Gulf region: U. S. Geol. Survey Prof. Paper 81, pp. 9-40, geologic map.

$$
\text { TENNESSEE, KENTUCKY, AND ILLINOIS. }
$$

1906. Glenn, L. C., Underground waters of Tennessee and Kentucky west of Tennessee River and of an adjacent area in Illinois: U. S. Geol. Survey Water-Supply Paper 164, 173 pp., geologic map.

$$
\text { ARKANSAS. }
$$

1906. Veatch, A. C., Geology and underground water resources of northern Louisiana and southern Arkansas: U. S. Geol. Survey Prof. Paper 46, 422 pp., geologic map.

1908. Branner, J. C., The clays of Arkansas: U. S. Geol. Survey Bull. 351, 247 pp., geologic map.

$$
\text { TEXAS. }
$$

1892. Dumble, E. T., Notes on the geology of the valley of the middle Rio Grande: Geol. Soc. America Bull., vol. 3, pp. 219-230.

1900. Vaughan, T. W., U. S. Geol. Survey Geol. Atlas, Uvalde folio (No. 64), 7 pp., geologic map.

1900. Vaughan, T. W., Reconnaissance in the Rio Grande coal fields of Texas: U. S. Geol. Survey Bull. 164, pp. 1-72 sketch map.

1901. Hill, R. T., Geography and geology of the Black and Grand prairies, Texas: U. S. Geol. Survey Twenty-first Ann. Rept., pt. 7, pp. 666, geologic map.

1902. Hill, R. T., and Vaughan, T. W., U. S. Geol. Survey Geol. Atlas, Austin folio (No. 76), 8 pp., geologic map.

1911. Gordon, C. H., Geology and underground waters of northeastern Texas: U. S. Geol. Survey Water-Supply Paper 276, 78 pp., geologic map.

1911. Dumble, E. T., Rediscovery of some Conrad forms: Science, new ser., vol. 33, pp. 970-971, 1911. 